
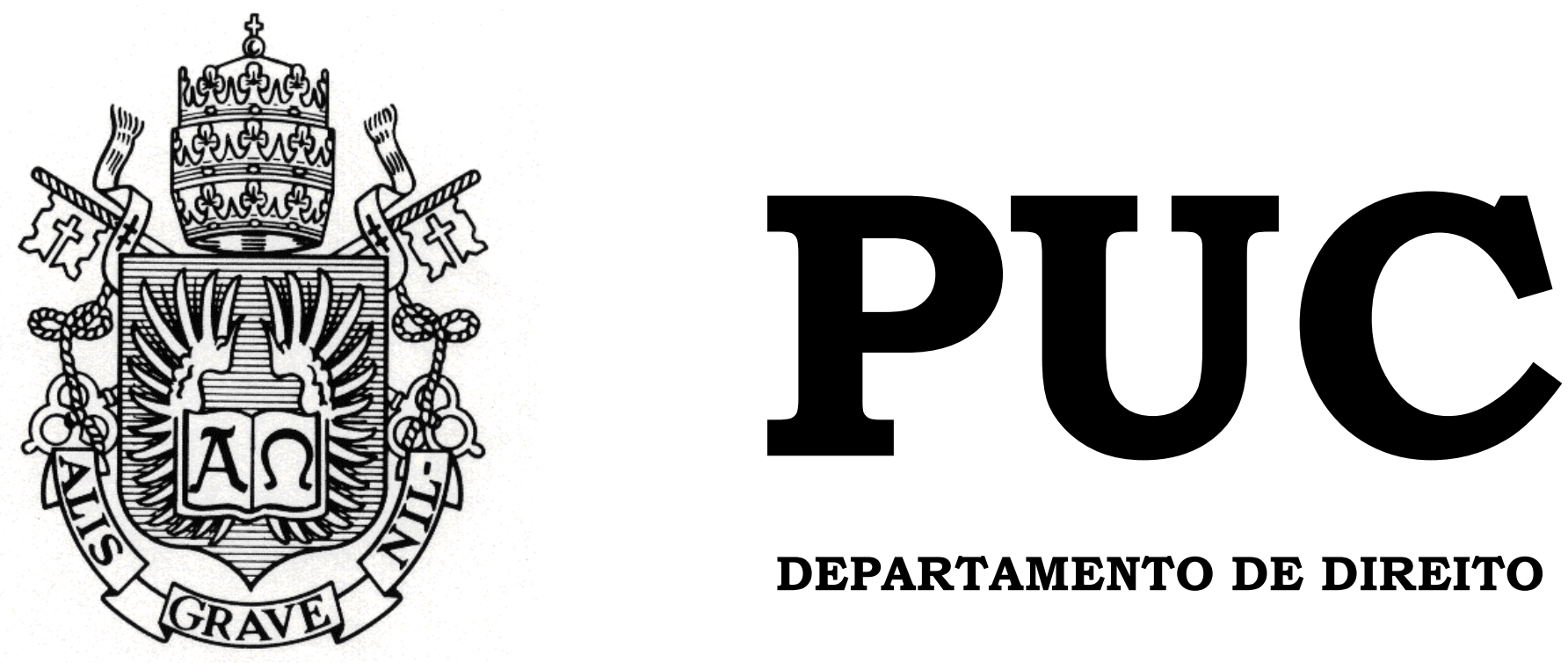

DEPARTAMENTO DE DIREITO

\title{
Cargas Probatórias Dinâmicas no Processo Civil Brasileiro
}

por

Daniel Dias Carneiro Guerra

ORIENTADOR: Dárcio Augusto Chaves Faria

2009.1

PONTIFÍCIA UNIVERSIDADE CATÓLICA DO RIO DE JANEIRO

RUA MARQUÊS DE SÃO VICENTE, 225 - CEP 22453-900

RIO DE JANEIRO - BRASIL 


\title{
Cargas Probatórias Dinâmicas no Processo Civil Brasileiro
}

\author{
por \\ Daniel Dias Carneiro Guerra
}

Monografia

apresentada

ao

Departamento de Direito da Pontifícia Universidade Católica do Rio de Janeiro (PUC-Rio) para a obtenção do Título de Bacharel em Direito.

Orientador: Dárcio Augusto Chaves Faria 
Dedico esta monografia aos meus irmãos: Diego, por ter compartilhado as primeiras páginas da estrada, e Matheus, por me manter motivado a conservá-la. 


\section{Agradecimentos:}

Aos meus pais, pelo sacrifício e pela fé incondicionais.

À Pequena Taça, por todo o companheirismo, carinho, paciência, atenção, relógios adiantados, paciência, ajuda, apoio, motivação, paciência, manias, otimismo, paciência...

À minha família, simplesmente por estar lá.

Aos meus amigos, por todas as idéias geniais que nunca mais conseguimos lembrar.

Ao Professor Dárcio Augusto Chaves Faria, pela orientação dedicada. 
"Oh, Mama, can this really be the end?"

(Bob Dylan, "Stuck Inside Of Mobile With The Memphis Blues Again") 


\section{RESUMO}

GUERRA, D. D. C. Cargas probatórias dinâmicas no processo civil brasileiro. 2009. 84 f. Monografia (Graduação em Direito) - Pontifícia Universidade Católica do Rio de Janeiro, Rio de Janeiro, 2009

O presente estudo tem por objetivo analisar a aplicabilidade da Teoria das Cargas Probatórias Dinâmicas, desenvolvida na Argentina e que propõe uma renovada forma de encarar o ônus da prova, no processo civil brasileiro. Para a consecução de tal empreitada, buscou-se identificar, frente a frente, a maneira como o problema do onus probandi é tratado no CPC brasileiro e as inovações propostas pela nova teoria argentina. Em um segundo momento, buscou-se avaliar a possibilidade de aplicação destas inovações no Brasil, colhendo argumentos no próprio ordenamento jurídico brasileiro e apontando suas condicionantes.

Palavras-chave: Processo Civil. Prova. Ônus da Prova. Teoria das cargas probatórias dinâmicas. 


\section{SUMÁRIO}

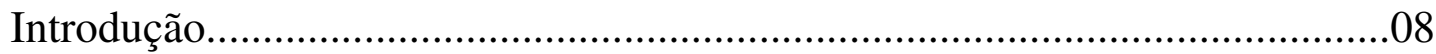

Capítulo I - Distribuição estática do ônus da prova...........................................11

1.1. Noção de ônus da prova........................................................................11

1.2. Estruturação do ônus da prova............................................................12

1.3. Distribuição estática do ônus da prova - art. 333 do CPC.......................15

1.4. Inconvenientes da distribuição estática do ônus da prova.....................18

Capítulo II - Distribuição dinâmica do ônus da prova........................................21

2.1. Teoria das cargas probatórias dinâmicas................................................21

2.2. A prova da melhor condição probatória da parte....................................28

2.3. A valoração da prova produzida pela parte em melhor condição

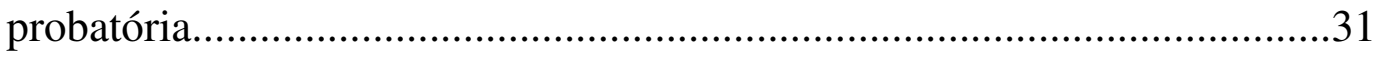

2.4. A nova Ley de Enjuiciamento Civil espanhola......................................35

Capítulo III - Distribuição dinâmica do ônus da prova no processo civil

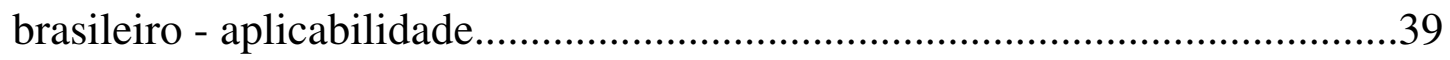

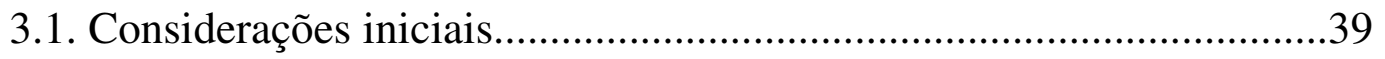

3.2. Ausência de expressa previsão legal....................................................40

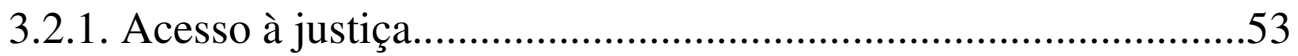

3.2.2. Princípio da igualdade................................................................54

3.2.3. Princípio da solidariedade e o dever de cooperação......................55

3.2.4. Princípio da adaptabilidade do procedimento.............................56

3.2.5. Ônus da prova nas relações de consumo.....................................57

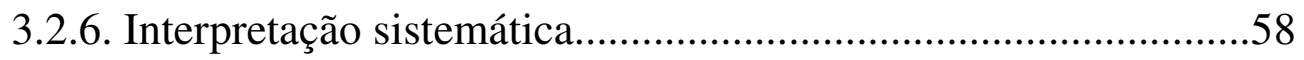

3.2.7. Jurisprudência...........................................................................59

3.3. Imprevisibilidade procedimental......................................................66 
3.4. Anteprojeto de Código Brasileiro de Processos Coletivos....................71

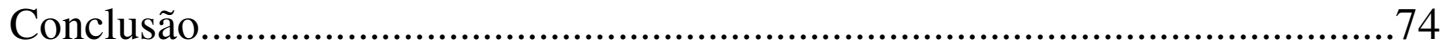

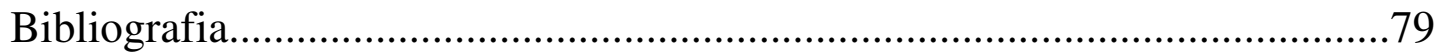




\section{INTRODUÇÃO}

No processo de conhecimento, a resolução da maior parte dos litígios depende, fundamentalmente, da elucidação de fatos ocorridos no passado. O autor, ao elaborar sua petição inicial, expõe os fatos e fundamentos jurídicos que embasam o seu pedido e o réu, salvo raríssimas exceções, refuta as alegações autorais, narrando sua versão dos fatos e requerendo que seja negada a tutela pretendida pelo autor.

O juiz, por sua vez, precisa, dentro do limite criado por esse conflito de versões sobre os acontecimentos (conflito de proposições) ${ }^{1}$, formar sua convicção sobre o desenrolar dos fatos, de forma que o permita decidir racionalmente o litígio em favor de uma das partes. É interessante recordar que o juiz, evidentemente, não estava presente quando os fatos narrados ocorreram - até porque, se estivesse, impedido estaria de atuar na causa como julgador ${ }^{2}-$ e, baseado apenas nas afirmações articuladas pelas partes, não dispõe de elementos suficientes para decidir.

Daí a importância crucial das provas no processo civil. Dentro do debate dialético instaurado no processo, as provas se apresentam como o meio retórico mais eficaz para influenciar no convencimento dos demais sujeitos processuais sobre determinado fato alegado. Uma adequada instrução probatória representa, muitas vezes, o próprio êxito do litigante na discussão instaurada.

\footnotetext{
${ }^{1}$ Ressalvadas as matérias cognoscíveis de ofício.

${ }^{2}$ Humberto Theodoro Júnior observa que "a influência do conhecimento extra-autos que o juiz detenha sobre a base fática da lide traduz-se em quebra da garantia do contraditório. A sentença, diante desse quadro, terá sido proferida sob a influência de elementos que não passaram pelo debate dialético da instrução probatória. O que não está nos autos não existe para o processo, segundo clássica parêmia de raízes romanas. $\mathrm{O}$ convencimento do juiz é livre, mas tem de ser formado apenas sobre os fatos e elementos do processo." (THEODORO JR., Humberto. Curso de direito processual civil: teoria geral do direito processual civil e processo de conhecimento. $47^{\mathrm{a}}$ ed. Rio de Janeiro: Forense, 2007. p. 236.)
} 
Por isso a relevância de se construir um procedimento probatório que permita às partes a mais ampla possibilidade de propor e produzir as provas que, a seu juízo, possam militar a favor do acolhimento de sua pretensão ou do não acolhimento da postulação de seu adversário $^{3}$, de maneira que os formalismos do processo não imponham obstáculos desarrazoados à efetiva participação das partes no debate, e, conseqüentemente, à própria possibilidade de se obter uma tutela jurisdicional plena.

E a discussão acerca deste procedimento probatório adequado, não aniquilador da concretização dos direitos assegurados pelo ordenamento jurídico, precisa passar, necessariamente, pela revisão da regra clássica de distribuição do ônus da prova, aperfeiçoada pela obra do ilustre processualista italiano Giuseppe Chiovenda e consagrada no art. 333 do Código de Processo Civil brasileiro. É preciso analisá-la em conjunto com as novas tendências do processo civil contemporâneo para avaliar se sua utilização indiscriminada é compatível com este procedimento probatório adequado que se pretende construir.

O objetivo do presente estudo é justamente participar desta análise, sem a pretensão, por razões óbvias, de esgotar os incontáveis contornos que ela pode receber. Neste trabalho, analisar-se-á somente a aplicabilidade da moderna teoria das cargas probatórias dinâmicas, desenvolvida na Argentina e que propõe uma renovada forma de encarar a distribuição do ônus da prova, no processo civil brasileiro. Para tanto, dividiu-se o trabalho em 3 (três) grandes capítulos:

No Capítulo I, far-se-á, além de uma análise introdutória acerca do conceito de ônus da prova, uma exposição sobre como o Código de Processo

\footnotetext{
${ }^{3}$ GRECO, Leonardo. As garantias fundamentais do processo: o processo justo. Disponível em: $<$ http://www.mundojuridico.adv.br/sis_artigos/artigos.asp?codigo=429>. Acesso em: 23 mai. 2009.
} 
Civil brasileiro lidou com o tema, apontando suas influências e avaliando suas deficiências.

No Capítulo II, analisar-se-á os fundamentos e implicações da teoria das cargas probatórias dinâmicas, através do estudo da obra de inúmeros processualistas argentinos e de alguns poucos brasileiros que já se aventuraram a escrever sobre o tema. Ao final, comentar-se-á a definitiva consagração legislativa da teoria na nova Ley de Enjuiciamento Civil espanhola, promulgada em janeiro de 2000.

Finalmente, no Capítulo III, analisar-se-á fundamentos e condicionantes para a aplicabilidade da teoria no processo civil nacional, levando em consideração os próprios contornos do ordenamento jurídico brasileiro e a obra de nossos juízes e doutrinadores. 


\section{DISTRIBUIÇÃO ESTÁTICA DO ÔNUS DA PROVA}

\subsection{Noção de ônus da prova}

A compreensão exata do tema exposto no presente estudo depende de uma prévia, ainda que superficial, explanação acerca do conceito de ônus processual e, mais especificamente, da noção de ônus da prova.

Segundo a definição de James Goldschimidt, ônus processuais representam a necessidade de prevenir, mediante a realização de um ato processual, um prejuízo processual e, em último caso, a obtenção de uma sentença desfavorável ${ }^{4}$.

Distinguem-se das obrigações, portanto, porque são imperativos do próprio interesse, ou seja, encargos cujo descumprimento expõe o próprio sujeito a uma situação de desvantagem no processo. Sobre esta distinção, discorria Francesco Carnellutti:

Obrigação e ônus têm em comum o elemento formal, consistente no vínculo da vontade, porém, divergem quanto ao elemento substancial, porque quando medeia obrigação, o vinculo se impõe para a tutela de um interesse alheio e quando há ônus, para a tutela de um interesse próprio ${ }^{5}$.

O sujeito, diante da imposição de um ônus, goza de liberdade para decidir se praticará ou não o ato, já que a sua inobservância é perfeitamente lícita. Não se deve confundir, entretanto, a noção de ônus com a de faculdade, uma vez que o não exercício desta implica apenas em não se auferir uma

\footnotetext{
${ }^{4}$ GOLDSCHMIDT, James. Teoria Geral do Processo. Trad. Leandro Farina. Cidade Jardim: Fórum, 2006. p. 73. Segundo o autor: "A causa jurídica consiste em que a luta das partes integra a essência do pleito, e em que impõe às partes a necessidade de atuar, quer dizer, de empregar os meios de ataque e defesa. E a consequiência do descuido da parte é o agravamento de sua situação processual, quer dizer, o inicio ou o aumento da perspectiva de uma sentença desfavorável."

${ }^{5}$ CARNELUTTI, Francesco. A Prova Civil. Trad. Lisa Pari Scarpa. $4^{a}$ ed. Campinas: Bookseller, 2005. p. 255.
} 
vantagem, enquanto que o descumprimento daquele pode gerar conseqüências desfavoráveis ${ }^{6}$.

Pode-se concluir, então, que a noção de ônus da prova, enquanto espécie da categoria ônus processual, está fundada na liberdade que os litigantes gozam para administrar as provas que produzirão no processo, mas cujo desempenho condicionará a majoração ou a minoração dos riscos de uma sentença desfavorável.

Afinal, quando se fala em ônus da prova, o simples cumprimento do encargo não garante a vitória no processo. Não basta à parte produzir a prova para que a sua pretensão ou a sua defesa sejam acolhidas, mas é necessário que a prova produzida, em cotejo com todo o acervo probatório disponível nos autos, seja capaz de convencer o juiz de que suas alegações são verdadeiras ${ }^{7}$.

No entanto, isso não retira a importância do ônus da prova, porque se a postura da parte perante o encargo não define automaticamente o resultado do processo, com certeza aquele que assume uma postura ativa diminui os riscos de uma decisão desfavorável. Por isso, afirma-se que o ônus da prova não determina quem deve produzir a prova, mas quem assume o risco pela sua nãoprodução ${ }^{8}$.

\subsection{Estruturação do ônus da prova}

\footnotetext{
${ }^{6}$ SOUZA, Wilson Alves de. Ônus da Prova: considerações sobre a doutrina das cargas probatórias dinâmicas. Revista Jurídica dos Formandos em Direito da UFBA, Salvador, v. 6, p.234-260, fev. 1999. p. 241.

CAMBI, Eduardo. A prova civil: admissibilidade e relevância. São Paulo: Revista dos Tribunais, 2006. p. 316.

${ }^{8}$ Ibid. p. 320.
} 
O ônus da prova, em um primeiro sentido, constitui uma regra de conduta dirigida às partes, que indica quais fatos a cada uma incumbe provar (ônus subjetivo). Pode ocorrer, entretanto, que as provas produzidas no processo não sejam suficientes para demonstrar os fatos alegados pelas partes. O juiz, mesmo na ausência de provas, tem o dever de julgar a lide, já que o Código de Processo Civil veda o non liquet ${ }^{9}$.

Por isso, afirma-se que o ônus da prova, em um segundo sentido, constitui uma regra de julgamento dirigida ao juiz, que indica que parte deverá suportar os riscos advindos da deficiência da atividade probatória, obtendo, conseqüentemente, uma sentença desfavorável (ônus objetivo).

Apesar de muito comum esta estruturação do ônus da prova, grande parte da doutrina questiona sua utilidade. Argumenta-se que, no curso da instrução, pouco importa quem efetivamente produziu a prova. O problema do onus probandi só surge quando as provas não foram satisfatoriamente produzidas e, chegado o momento de decidir, o juiz deve atribuir esta deficiência a um dos litigantes. Nesse sentido, dispõem os processualistas Fredie Didier Jr., Paula Braga e Rafael Oliveira:

Na realidade, ao julgador é suficiente que verifique se o resultado da instrução foi completo ou não. Se completo, irrelevante é quem foi o responsável pela produção da prova. O magistrado não deve se ater ao aspecto subjetivo do ônus probatório, não importando quem foi o responsável pela produção da prova - se o titular do ônus de produzi-la ou, eventualmente, a contraparte. Uma vez trazida a prova ao feito ela se desgarra daquela que a produziu, passando a fazer parte do processo - é o que dispõe o princípio da aquisição processual ou da comunhão das provas. Mas se incompleto (o resultado da instrução), deverá ater-se ao caráter objetivo do ônus probatório,

\footnotetext{
${ }^{9}$ Art. 206. O juiz não se exime de sentenciar ou despachar alegando lacuna ou obscuridade da lei. No julgamento da lide caber-lhe-á aplicar as normas legais; não as havendo, recorrerá à analogia, aos costumes e aos princípios gerais de direito.
} 
investigando qual das partes foi responsável pela sua incompletude, para que suporte os prejuízos da inexatidão fática que permaneceu nos autos ${ }^{10}$.

Para esta posição doutrinária, que conta com adeptos de peso, as regras de distribuição do ônus da prova somente apresentam relevância ao órgão judicial se, depois de encerrada a instrução, permanecem dúvidas razoáveis acerca dos fatos alegados. Percebe-se que, ao ignorar o ônus subjetivo, a preocupação se concentra exclusivamente no conteúdo da decisão judicial (ônus objetivo).

No entanto, conforme pondera Eduardo Cambi, é interessante lembrar que o ônus da prova, em sentido objetivo, deverá ser suportado necessariamente por uma das partes. A noção de ônus da prova não pode prescindir de um componente subjetivo, porque é uma categoria jurídica que não pode ser concebida sem um titular. A falta de certeza, que determina ao juiz aplicar o ônus da prova em sentido objetivo, é inseparável do risco que pesa sobre a parte que não produz as provas de suas alegações. Portanto, "o aspecto objetivo do ônus da prova está ligado, intrinsecamente, ao subjetivo, não podendo ser desprezado.",11

Além disso, o juiz moderno, livre das amarras da neutralidade liberal, jamais poderia ser indiferente à atividade das partes, sendo sua função estimulá-las a apresentar as provas que lhe incumbem, possibilitando-as, através do estabelecimento de um diálogo humano, a participar e, sobretudo, influir na formação de seu convencimento ${ }^{12}$. Dessa forma, muito embora se

\footnotetext{
${ }^{10}$ DIDIER JR., Fredie; BRAGA, Paula Sarno; OLIVEIRA, Rafael. Curso de Direito Processual Civil: direito probatório, decisão judicial, cumprimento e liquidação da sentença e coisa julgada. $2^{\mathrm{a}}$ ed. Salvador: Juspodivm, 2008. p. 74.

${ }^{11}$ CAMBI, Eduardo. A prova civl. p. 318.

${ }^{12}$ Nesse mesmo sentido, dispõe Cândido Rangel Dinamarco: "De minha parte, vou entendendo que o juiz deve estar atento às regras do ônus da prova e ao desempenho das partes ao longo de toda a instrução da causa. A regra do diálogo, inerente à garantia constitucional do contraditório em sua feição moderna, integra o chamado ativismo judicial e exige que o juiz esclareça as partes sobre os
} 
reconheça que a regra de distribuição do ônus da prova tenha como função preponderante iluminar o magistrado que chega ao final do processo em estado de dúvida, não se pode desprezar sua importância durante toda a fase de instrução, quando influenciará diretamente na atividade das partes e permeará a formação da própria convicção do magistrado.

\subsection{Distribuição estática do ônus da prova - art. 333 do CPC}

O Código de Processo Civil de 1973, em muito não destoando do CPC de $1939^{13}$, levou em consideração dois fatores para distribuir o ônus da prova: (i) a posição das partes no processo (se autor ou réu) e (ii) a natureza dos fatos que fundam as suas pretensões e exceções. Assim, cabe ao autor a prova dos fatos constitutivos de seu direito, e ao réu a prova dos fatos impeditivos, extintivos ou modificativos deste mesmo direito (art. 333).

Percebe-se que este critério está baseado no interesse na afirmação do fato e na prova de sua existência. $\mathrm{O}$ autor, por ser o maior interessado no acolhimento de sua pretensão, deve exercer uma posição ativa no processo, sendo gravado com o ônus de provar os fatos constitutivos de seu direito. $\mathrm{O}$ réu, por sua vez, como geralmente está interessado na manutenção do status quo, exerce uma posição defensiva, sendo, por isso, gravado com o ônus de provar os fatos negativos (extintivos, impeditivos ou modificativos) à pretensão do autor. ${ }^{14}$

rumos da instrução, conclamando-as a complementar provas." (DINAMARCO, Cândido Rangel. A instrumentalidade do processo. $3^{\mathrm{a}}$ ed. São Paulo: Malheiros Editores, 1993. p. 249.)

${ }^{13} \mathrm{O}$ art. 209 do CPC de 1939 dispunha: O fato alegado por uma das partes, quando a outra não contestar, será admitido como verídico se o contrário não resultar do conjunto das provas. $\S 1^{\circ}$. Se o réu, na contestação, negar o fato alegado pelo autor, a este incumbirá o ônus da prova. $\S 2^{\circ}$. Se o réu, reconhecendo o fato constitutivo, alegar a sua extinção, ou a ocorrência de outro que lhe obste os efeitos, a ele incumbirá provar a alegação.

${ }^{14}$ CAMBI, Eduardo. A prova civil. p. 324. 
Entende-se por fato constitutivo aquele que dá vida a "uma vontade concreta da lei e à expectativa de um bem por parte de alguém." ${ }^{\prime 1}$. Por exemplo: um ato ilícito e culposo, causador de um dano, constitui o fato constitutivo do direito de indenização.

É interessante notar que, em princípio, a posição do réu é mais cômoda do que a do autor no processo, uma vez que nenhum ônus probatório recai sobre ele até que o autor prove o fato constitutivo de seu direito ${ }^{16}$. Se, chegado ao final da instrução, o juiz ainda não estiver convencido das alegações autorais, a demanda será julgada improcedente, independente da atividade probatória do réu. Isso porque o juiz, na ausência de provas e sem ter motivos suficientes para conferir maior credibilidade às alegações do demandante do que às do demandado, deve julgar a favor deste, mantendo as coisas como estavam antes da propositura da demanda.

No entanto, estando provado o fato constitutivo do direito do autor, sobre o réu recairão duas exigências de esforço probatório: a primeira, fundada na chamada defesa direta de mérito ${ }^{17}$, consiste em contraprovar o fato demonstrado pelo autor; e a segunda, fundada na chamada defesa indireta de mérito ${ }^{18}$, consiste em provar os fatos negativos à pretensão do autor.

Observe que, muito embora o CPC não faça expressa menção ao ônus do réu de contraprovar o fato constitutivo do direito do autor, é evidente que se

\footnotetext{
${ }^{15}$ CHIOVENDA, Giuseppe. Instituições de Direito Processual Civil. São Paulo: Saraiva, 1969, v. 1. p. 07.

${ }^{16}$ Nesse ponto, é importante frisar que não recai sobre ele nenhum ônus probatório, no entanto, o réu permanece com o ônus de comparecer ao processo e impugnar especificamente os fatos alegados pelo autor.

${ }^{17} \mathrm{Na}$ defesa direta de mérito, o "réu não alega nenhum fato novo, a ampliar o conteúdo fático da demanda como proposta pelo autor; limita-se o requerido a negar a ocorrência dos fatos deduzidos pelo autor (...)" (MARINONI, Luiz Guilherme; ARENHART, Sérgio Cruz. Curso de Processo Civil v. 2: Processo de Conhecimento. $7^{\mathrm{a}}$ ed. São Paulo: Revista dos Tribunais, 2008. p. 134.)

${ }^{18} \mathrm{Na}$ defesa indireta de mérito, o "réu alega fato novo, ampliando o conteúdo fático da demanda, fato este capaz de impedir ou modificar a realização do direito afirmado pelo autor, ou ainda extingui-lo." (Ibid. p. 135)
} 
ele se limitou a negar a existência do fato (defesa direta de mérito), sem aduzir nada de novo, recairá sobre ele o ônus de produzir esta (contra) prova.

Por outro lado, se o réu, apesar de admitir o fato constitutivo do direito do autor, alega a ocorrência de novos fatos que obstam ou modificam este direito (defesa indireta de mérito), ampliando o objeto de cognição, sobre ele recairá o ônus de prová-los. Como prevê o CPC, são três os tipos de fatos novos que o réu pode aduzir:

O fato extintivo, em oposição ao fato constitutivo, é aquele que "faz cessar a vontade concreta da lei e a conseqüente expectativa de um bem"19, como o pagamento, a compensação, a prescrição, a decadência legal, etc.

Já o fato impeditivo é um fato de conteúdo negativo, ou seja, a ausência de algum dos requisitos genéricos de validade de um ato jurídico (agente capaz, objeto lícito, forma prescrita ou não defesa em lei). Incumbe ao réu, por exemplo, demonstrar ao juiz que o agente era menor de 18 (dezoito) anos no momento da contratação ${ }^{20}$.

Por fim, o fato modificativo é aquele que, tendo como certas a existência e a eficácia do direito, busca, tão-somente, alterá-lo, como o pagamento parcial ou a moratória concedida ao devedor ${ }^{21}$.

Como se percebe, o CPC brasileiro adotou uma concepção estática do ônus da prova, ao definir, de forma rígida e prévia, que cada parte assume o ônus de provar o que alegou (ou de contraprovar o que foi alegado e provado pelo adversário), sem observar quaisquer particularidades do caso concreto.

\footnotetext{
${ }^{19}$ CHIOVENDA, Giuseppe. Instituições de Direito Processual Civil. v. 1. p. 08.

${ }^{20}$ CÂMARA, Alexandre Freitas. Lições de Direito Processual Civil. $18^{\mathrm{a}}$ ed. Rio de Janeiro: Lumen Juris, 2008. v. 1. p. 379.

${ }^{21}$ DIDIER JUNIOR, Fredie; BRAGA, Paula Sarno; OLIVEIRA, Rafael. Curso de Direito Processual Civil: direito probatório, decisão judicial, cumprimento e liquidação da sentença e coisa julgada. p. 78.
} 
Consagrou, com isso, a concepção de um processo civil visivelmente marcado pela idéia de competição (ou disputa), onde cada parte deve se valer dos meios persuasivos de acordo com a sua própria perspicácia, sendo indiferente ao juiz eventual desequilíbrio que a realidade concreta possa revelar.

\subsection{Inconvenientes da distribuição estática do ônus da prova}

Em primeiro lugar, é importante ressaltar que a regra estática de distribuição do ônus da prova, consagrada no art. 333 do CPC, demonstra, em princípio, uma lógica indiscutível. "Não há racionalidade em exigir que alguém que afirma um direito deva ser obrigado a se referir a fatos que impedem o seu reconhecimento pelo juiz" ${ }^{22}$. Isso deve ser feito pelo réu, quem pretende que o direito não seja reconhecido. A coerência da distribuição é inegável.

Entretanto, esta regra, assim como qualquer outra produção da inteligência humana, guarda íntima relação com os valores e pensamentos dominantes na época de sua elaboração ${ }^{23}$. Todo o CPC de 1973, e a regra do

\footnotetext{
${ }^{22}$ MARINONI, Luiz Guilherme; ARENHART, Sérgio Cruz. Curso de Processo Civil v. 2. p. 267. Fundamentando esta afirmação, seguem os autores: "Na Alemanha, onde não há norma similar à do art. 333 do CPC, a idéia de distribuição do ônus da prova segue a mesma lógica. Argumenta-se que a parte que pretende ser beneficiada pelos efeitos de uma norma deve provar os pressupostos fáticos para a sua aplicação. Se, para a aplicação de uma norma, são relevantes os fatos constitutivos, impeditivos, modificativos e extintivos, aquele que deseja a produção dos seus efeitos deve provar somente os fatos que são exigidos para a sua aplicação, e não os que impedem a sua aplicação, ou modificam ou extinguem o direito. Na ausência de regra expressa sobre a divisão do ônus da prova, a doutrina alemã, desenvolvendo a idéia de que a discussão em torno da aplicação de uma norma pode girar em torno dos fatos constitutivos, impeditivos, modificativos e extintivos, chegou à conclusão lógica de que o autor somente deveria provar os fatos pressupostos para a aplicação da norma, e o réu os fatos impeditivos, modificativos ou extintivos. Por isso, a teoria que expressou tal problemática ficou conhecida como Normantheorie."

${ }^{23}$ Utilizando-nos da metáfora de CAPPELLETTI: "O direito processual, resumindo, pode ser considerado (...) um espelho no qual, com extrema fidelidade, se refletem os movimentos do pensamento, da filosofia e da economia de um determinado período histórico." (CAPPELLETTI, Mauro. O Processo Civil no Direito Comparado. Trad. Hiltomar Martins de Oliveira. São Paulo: Líder, 2001. p. 18.)
} 
ônus da prova não é exceção, foi nitidamente influenciado pela escola processual italiana do início do séc. XX, cuja principal preocupação era desvincular o direito processual civil do direito material e de evidenciar a natureza pública do processo ${ }^{24}$.

Esta doutrina, capitaneada, sobretudo, pelo processualista Giuseppe Chiovenda, na ânsia de construir as bases da autonomia do processo, acabou gerando uma ciência processual que, além de autônoma, se mostrou completamente indiferente ao direito material. $\mathrm{O}$ estudo do processo, portanto, muito embora tenha ganhado dignidade científica própria, e essa é uma das grandes conquistas desta escola, passou a se valer de conceitos gerais e abstratos que pudessem abarcar quaisquer situações fáticas. Além disso, conquanto não se possa afirmar que a escola chiovendiana estava profundamente imersa na ideologia do estado liberal clássico, é evidente que os valores liberais tiveram grande peso nos seus estudos.

Portanto, quando o Código de Processo Civil brasileiro distribui o encargo probatório entre as partes, valendo-se exclusivamente da posição que os litigantes ocupam na relação processual e da natureza do fato probando, deixa transparecer toda a influência que a doutrina chiovendiana exerceu sobre ele. Isso porque ignora a realidade concreta das partes, sendo indiferente a quaisquer obstáculos (sociais, culturais ou econômicos) que possam dificultar, ou até mesmo impossibilitar, que a parte produza a prova que lhe foi previamente incumbida. Deixa transparecer, dessa forma, uma preocupação típica do estado liberal que, em nome da garantia da liberdade dos homens, construiu a idéia da igualdade formal de todos perante a lei, proibindo-se ao

\footnotetext{
${ }^{24}$ MARINONI, Luiz Guilherme. Técnica Processual e Tutela dos Direitos. $2^{\mathrm{a}}$ ed. São Paulo: Revista dos Tribunais, 2008. p. 42.
} 
legislador estabelecer qualquer tratamento diversificado às diferentes posições sociais $^{25}$.

Por outro lado, prestigia outro pecado capital da escola chiovendiana: a pretensão de uniformização do procedimento ${ }^{26}$. Ora, é mais do que natural que uma escola que tivesse como meta principal o isolamento do processo em face do direito material, insistisse na criação de um procedimento único para atender a diferentes situações de direito material. Isso fica evidente na regra de distribuição do encargo probatório que, através de um imperativo inflexível, pretende tutelar adequadamente todos os casos concretos, ignorando, assim, as particularidades dos fatos objetos de prova.

Diante disso, a pergunta que deve ser formulada, agora, é se esta regra, construída sob a influência do pensamento e dos valores de uma época ultrapassada, permanece, enquanto tomada como algo rígido e absoluto, plenamente válida diante das aspirações e das necessidades de nosso Estado Democrático de Direito ${ }^{27}$ ?

\footnotetext{
${ }^{25}$ MARINONI, Luiz Guilherme. Técnica Processual e Tutela dos Direitos. p. 45.

${ }^{26}$ Ibid. p. 42.

${ }^{27}$ Retomando a metáfora de CAPPELLETTI: será que nosso espelho (o processo) permanece a refletir os movimentos do pensamento, da filosofia e da economia de nossa geração?
} 


\section{DISTRIBUIÇÃO DINÂMICA DO ÔNUS DA PROVA}

\subsection{A teoria das cargas probatórias dinâmicas}

A influência da escola chiovendiana não foi, evidentemente, privilégio dos processualistas brasileiros. Os estudos desenvolvidos na Itália do início do séc. XX representaram uma das maiores evoluções na seara do processo civil de tradição romanista, sendo responsáveis pela definitiva evidenciação da natureza pública do processo e pela sedimentação de diversos institutos jurídico-processuais. A nova ciência processual, enfim reconhecidamente autônoma, encantou pela racionalidade de suas teorizações e seus reflexos podem ser notados na maioria dos códigos da Europa Ocidental e da América Latina, elaborados ao longo do século passado.

O encantamento gerado pela escola chiovendiana foi de tal magnitude, que muitos de seus conceitos, delineados a partir da necessidade de se desvincular o direito processual civil do direito material, acabaram se tornando verdadeiros "dogmas" que, seja pela validade de seus fundamentos, seja pela inibição que tamanha influência pode gerar, foram repetidos exaustivamente pela doutrina processual moderna ${ }^{28}$. Conforme argumenta a jurista argentina Inés Lépori White, "la doctrina procesal se enamoró tanto de sus obras (...) que prefirió verlas solas y aisladas, lejos incluso de la matéria sobre la que iban a ser aplicadas y a la cual debían aprovechar,"29.

\footnotetext{
${ }^{28}$ Exemplificando esta afirmação, vale transcrever a seguinte constatação de MARINONI: "Ainda são sustentadas, depois de aproximadamente cem anos, as teorias de que a jurisdição tem a função de atuar a vontade concreta da lei - atribuída a Chiovenda - e de que o juiz cria a norma individual para o caso concreto, relacionada com a tese da 'justa composição da lide' - formulada por Carnelutti."' MARINONI, Luiz Guilherme. Teoria Geral do Processo. $3^{\text {a }}$ ed. São Paulo: Revista dos Tribunais, 2008. p. 23.

${ }^{29}$ WHITE, Inés Lépori. Cargas probatorias dinámicas. In: PEYRANO, Jorge W. (Director); WHITE, Inés Lépori (Coordinadora). Cargas probatorias dinámicas. 1a ed. Santa Fe: Rubinzal-Culzoni, 2008. Cap. 4, p. 35-73. p. 64.
} 
Pode-se afirmar, com isso, que a influência exercida pela escola chiovendiana, apesar de ter representado significativa evolução no estudo do processo civil, culminou em uma natural estagnação da doutrina que a sucedeu $^{30}$. O distanciamento entre o direito substancial e o processo civil, cultivado por uma necessidade contextual da escola chiovendiana, foi alimentado pela doutrina através do tempo, muito embora o contexto já tivesse sido definitivamente alterado.

Isso pode ser claramente evidenciado no tratamento dispensado às regras de distribuição do ônus da prova. De acordo com a teoria clássica, aperfeiçoada pelo trabalho de Giuseppe Chiovenda, a divisão do ônus da prova era feita de forma demasiadamente rígida e sem levar em conta quaisquer particularidades das circunstâncias do caso concreto (circunstâncias que, eventualmente, poderiam aconselhar alguma outra solução) ${ }^{31}$. Afirmava-se que, em quaisquer casos, ao autor cabia a prova dos fatos constitutivos de seu direito, enquanto que ao réu caberia a prova dos fatos extintivos, impeditivos ou modificativos do direito do autor.

Estabelecida esta regra estática, a discussão doutrinária acerca do ônus probatório se limitou a circundá-la durante muito tempo ${ }^{32}$. Apesar de grandes

\footnotetext{
${ }^{30}$ Nesse contexto, vale transcrever, mais uma vez, as palavras de Inés Lépori White: "Hace algunos años entendí que la virtud de tener tan grandes maestros en la materia, y la nuestra los tiene em exceso, venia casi siempre acompañada por el peligro de que se inmovilizaran muchas de sus instituciones, tornándose extremadamente rígidas o por lo menos sin la necesaria flexibilidad para adaptarse a los cambios, y esto en razón de que, aparentemente, ya todo se había dicho, estudiado o analizado, y de manera difícilmente superable. Hay que reconocer también que las doctrinas o las instituciones no se vuelven rígidas por sí solas; somos nosotros, los que nos servimos de ellas, quienes por comodidad o conveniencia muchas veces evitamos avanzar hacia el cambio." (WHITE, Inés Lépori. Cargas probatorias dinámicas. p. 38)

${ }^{31}$ PEYRANO, Jorge W; CHIAPPINI, Julio O. Liniamentos de las cargas probatorias "dinámicas". In: PEYRANO, Jorge W. (Director); WHITE, Inés Lépori (Coordinadora). Cargas probatorias dinámicas. $1^{a}$ ed. Santa Fe: Rubinzal-Culzoni, 2008. Cap. 1, p. 13-18. p. 15.

${ }^{32}$ É verdade que existiram outras tantas teorias que procuraram sistematizar de maneira diferente o onus probandi, como, por exemplo, a teoria de Leo Rosenberg, segundo a qual cada parte deveria afirmar e provar os pressupostos fáticos das normas que lhe são favoráveis. Entretanto, nenhuma das
} 
autores apontarem eventuais problemas perpetuados pela aplicação generalizada da regra clássica, poucas soluções concretas foram amplamente estudadas e difundidas. A regra estática do ônus da prova permaneceu, e ainda hoje permanece para alguns, como o único ultimum refugium legítimo do juiz para evitar o non liquet.

Eis que a jurisprudência - onde a ciência finalmente encontra a realidade - argentina alertou a doutrina de que esta regra absolutamente estática poderia conduzir a resultados manifestamente injustos, pois, em determinadas situações, é materialmente impossível, ou extremamente difícil, que a parte produza a prova que lhe foi previamente incumbida ${ }^{33}$. Os juízes argentinos, diante dessas situações de probatio diabolica, buscaram meios de flexibilizar as tradicionais regras do onus probandi, encontrando soluções que transbordavam os próprios contornos legais e buscavam a justiça aplicada ao caso concreto.

A partir dessas decisões, a doutrina argentina, sobretudo através da obra dos ilustres processualistas Jorge Peyrano e Augusto Morello, desenvolveu a "teoría de las cargas probatorias dinámicas" - também denominada de

teorias desenvolvidas conseguiu se libertar da rigidez e da abstração consagradas pela regra clássica de distribuição do ônus da prova, heranças, a nosso ver, da escola chiovendiana.

${ }^{33}$ Aliás, o relacionamento entre os juízes e o ônus da prova como regra de julgamento sempre foi delicado, como se pode aferir nessa bela passagem de José Carlos Barbosa Moreira: "A insistência do juiz em esclarecer cabalmente ponta a cujo respeito lhe pareçam faltar informações completa nos autos, levada às últimas consequiências, pode acarretar demora excessiva na solução do litígio. A garantia do contraditório estará posta em causa se ao órgão judicial parecer que a testemunha a ser interrogada se expressaria com maior liberdade, e portanto prestaria depoimento mais útil, fora da presença da parte, que a constrange e inibe. A observância rigorosa de uma regra preclusão processual talvez prive o juiz da aquisição de elemento probatório particularmente valioso. Esse e outros tantos conflitos entre soluções legítimas, a puxá-lo cada qual para um lado, assaltam a todo momento o espírito do julgador. Se ele o tem muito sensível, dificilmente se tranqüilizará, em qualquer caso, com a lembrança da tábua de salvação que a lei lhe atira, quando lhe permite contornar as remanescentes manchas escuras da matéria fática pela simples aplicação das normas legais de distribuição do ônus da prova: é uma saída de que não há como prescindir, mas cuja utilização costuma deixar certo ressaibo amargo na mente do juiz consciencioso." (MOREIRA, José Carlos Barbosa Moreira. Temas de direito processual: quarta série. São Paulo: Saraiva, 1989. p. 160.) 
"solidaridad de la prueba" ou "prueba compartida"34 - que propõe uma flexibilização, diante de casos excepcionais, do onus probandi tradicional, para que o encargo probatório recaia, principalmente, sobre a parte que está em melhores condições técnicas, profissionais ou fáticas para dele se desincumbir, independente de sua posição no processo (se autor ou réu) ou da natureza do fato probando (se constitutivo, extintivo, impeditivo ou modificativo) ${ }^{35}$.

Esta teoria rompe com a concepção estática da distribuição tradicional do ônus da prova, pautada exclusivamente em pressupostos rígidos e abstratos, para adotar uma concepção dinâmica, imputando-se o onus probandi àquela parte que, pelas circunstâncias reais, se encontra em melhores condições de cumpri-lo $^{36}$. Representa, dessa forma, um importantíssimo passo na reaproximação do direito processual com o direito material, que é o grande desafio do processo civil moderno.

Seu surgimento, conforme observa Jorge Peyrano, foi impulsionado pela necessidade de se aliviar a ingrata tarefa da vítima, paciente de um ato

\footnotetext{
${ }^{34}$ Apesar das diferentes denominações, Jorge Peyrano ressalta que todas guardam um ideário comum. Utilizamo-nos, no presente estudo, da denominação “Teoria das Cargas Probatórias Dinâmicas", pois foi a denominação que ganhou maior notoriedade no Brasil. Outro dado curioso é que o vocábulo "carga", utilizado pela doutrina argentina, é o termo espanhol correspondente à palavra portuguesa "ônus", portanto, a tradução mais correta seria "Teoria do Ônus Probatório Dinâmico". Por questões práticas, manteremos a tradução difundida no meio acadêmico brasileiro.

${ }^{35}$ Nesse ponto, vale ressaltar que esta forma de distribuir o encargo probatório não é necessariamente nova, nem tampouco argentina. Jeremy Bentham, jurista e filósofo inglês, afirmava, já em 1823, que o ônus da prova deveria ser imposto à parte que pudesse cumpri-lo com menos inconvenientes. Entretanto, não se pode perder de vista que Benthan foi, ao lado de John Stuart Mill, um dos responsáveis pela sistematização e divulgação do Utilitarismo, corrente filosófica cujo princípio geral poderia ser sistematizado como "uma ação moralmente correta é a que produz maior prazer e/ou menor sofrimento para maioria.". Portanto, quando Bentham afirmava que a prova deveria recair sobre a parte que estivesse em melhores condições de produzi-la, levava em conta apenas aspectos econômicos, egoísticos e particulares, como menor perda de tempo, menores incômodos e menores despesas, para que a instrução probatória fosse realizada de maneira a maximizar a sua utilidade e minimizar seus inconvenientes. Dessa forma, pode-se afirmar, sem maiores questionamentos filosóficos, que a distribuição dinâmica do ônus da prova, se não foi uma criação exclusivamente argentina, com certeza ganhou seus atuais contornos e fundamentos através do trabalho dos processualistas hermanos, que revigoraram seu ideário em harmonia com os novos paradigmas do processo civil.

36 DALl'AGNOL JR., Antonio Janyr. Distribuição Dinâmica dos Ônus Probatórios. Revista dos Tribunais, São Paulo, v. 788, p.93-107, jun. 2001. Mensal. p. 98.
} 
cirúrgico, de produzir a prova da conduta culposa dos médicos intervenientes, em casos de responsabilidade civil subjetiva. Isso porque, segundo as regras clássicas de distribuição do onus probandi, este encargo recairia inteiramente sobre a cabeça da vítima que, além de se encontrar completamente anestesiada durante o acontecimento dos fatos, dificilmente detinha conhecimentos técnicos específicos capazes de demonstrar que o réu agiu em desconformidade com a praxe médica. Ao réu, para que se sagrasse vitorioso, bastaria adotar uma postura probatória inerte no processo, já que, segundo a regra tradicional, a ausência de prova do fato constitutivo do direito do autor conduz à improcedência do pedido, independente das provas produzidas pelo réu.

A teoria das cargas probatórias dinâmicas surge, fundamentalmente, para equilibrar esta situação de desigualdade entre as partes no processo, cuja manutenção tornaria completamente inútil a demanda proposta pela vítima e brindaria a inércia probatória do cirurgião. De acordo com a regra dinâmica, em casos como este, o encargo probatório recairia sobre ambas as partes, mas em especial sobre o cirurgião, pois é quem, evidentemente, goza de melhores condições (técnicas, profissionais e fáticas) para promover uma adequada reconstrução dos fatos, cabendo a ele demonstrar que atuou dentro do conhecimento e da técnica da ciência que domina e que, portanto, eventual resultado danoso não lhe poderia ser imputado.

Conforme observa o desembargador gaúcho Antonio Janyr Dall'Agnol Junior, esta nova teoria propõe uma visão mais solidarista do encargo de provar, superando-se a de feição extremamente individualista (e patrimonialista) do processo civil clássico ${ }^{37}$. O princípio da solidariedade, segundo a lição de Augusto Morello, obriga, como ônus técnico do processo,

\footnotetext{
${ }^{37}$ DALL'AGNOL JR., Antonio Janyr. Distribuição Dinâmica dos Ônus Probatórios. p. 99.
} 
que a parte em melhores condições fáticas produza a prova do fato controvertido sem se refugiar no seu mero interesse particular ${ }^{38}$.

A advogada argentina Ivana María Airasca sustenta que a teoria está fundada no dever das partes de se conduzirem com lealdade, probidade e boafé no processo, no dever de colaboração na elucidação dos fatos controvertidos e no dever de cooperação com o órgão jurisdicional, para que este possa proferir uma sentença verdadeiramente justa ${ }^{39}$. O jurista baiano Wilson Alves de Souza, valendo-se da lição de Augusto Morello, observa que o magistrado, agora com poderes e responsabilidades ainda mais amplos, deve estar atento às particularidades do caso concreto e à conduta processual das partes e, caso verifique que houve quebra do dever de cooperação, deve julgar contra o infrator, já que a conduta processual das partes passa a constituir um importante elemento de convicção, ao lado dos indícios e das presunções ${ }^{40}$.

Em outra linha de argumentação, mas com um ideário muito próximo, Miryam Balestro Faure afirma que a teoria das cargas probatórias dinâmicas é uma projeção processual da teoria do abuso de direito, cujo princípio proibitivo impediria que a parte em melhores condições de provar se quedasse absolutamente inerte, amparada na comodidade de um encargo prévia e abstratamente estipulado, pois esta conduta omissiva excederia os limites impostos pelo dever de litigância de boa-fé ${ }^{41}$.

\footnotetext{
${ }^{38}$ SOUZA, Wilson Alves de. Ônus da Prova: considerações sobre a doutrina das cargas probatórias dinâmicas. p. 245.

39 AIRASCA, Ivana Maria. Reflexiones sobre la doctrina de las cargas probatorias dinámicas. In: PEYRANO, Jorge W. (Director); WHITE, Inés Lépori (Coordinadora). Cargas probatorias dinámicas. $1^{a}$ ed. Santa Fe: Rubinzal-Culzoni, 2008. Cap. 8, p. 125-152. p. 141.

${ }^{40}$ SOUZA, Wilson Alves de. op. cit. p. 245.

41 FAURE, Miryam Balestro. Una proyección del principio que prohíbe abusar de los derechos procesales. In: PEYRANO, Jorge W. (Director); WHITE, Inés Lépori (Coordinadora). Cargas probatorias dinámicas. $1^{\mathrm{a}}$ ed. Santa Fe: Rubinzal-Culzoni, 2008. Cap. 15, p. 321-364. p.321.
} 
$\mathrm{Na}$ Argentina, apesar de algumas tentativas frustradas de restrição, a teoria teve intensa aceitação no meio acadêmico, tendo sido considerada como “doctrina ya recebida" pelo XVII Congreso Nacional de Derecho Procesal, realizado em maio de 1993, cuja conclusão é bastante elucidativa:

Constituye doctrina ya recebida la de las cargas probatorias dinámicas. La misma importa un apartamiento excepcional de las normas legales sobre la distribuición de la carga de la prueba, a la que resulta solo cuando la aplicación de aquélla arroja consecuencias manifiestamente disvaliosas. Dicho apartamiento se traduce em nuevas reglas de reparto de la imposición probatoria ceñida a las circunstancias del caso y renuente a enfoques apriorísticos (tipo de hecho a probar, rol de actor o demandado, etc. $)^{42}$.

Fica claro, através da leitura desta conclusão, que a simples existência do enfoque dinâmico do ônus da prova não importa no afastamento completo da teoria clássica; muito pelo contrário. A teoria clássica continua a existir como regra geral, só que agora complementada e aperfeiçoada pela flexibilidade da teoria das cargas probatórias dinâmicas ${ }^{43}$, cuja aplicação só é legítima naqueles casos em que a regra clássica conduziria a resultados manifestamente iníquos. Nesse sentido, vale destacar as palavras do próprio Peyrano:

Por fin, se vuelve a subrayar la calidad - por ahora, al menos - de la doctrina "de excepción" que debe reconocerse a la de las "cargas probatorias dinámicas" pensada por y para dar adecuada solución a causas que, de lo contrario, recibirían respuestas jurisdiccionales inequivocamente inicuas. Que, entonces, no se interprete mal. De lo que trata es, pues, no de propiciar outra regla rígida de distribuición de la carga de la prueba que concurre en pie de igualdad con los parámetros legalmente regulados, sino de formular una pauta "excepcional" que solo puede funcionar allí donde aquéllas manifiestamente operan mal porque fueron elaboradas para supuestos "normales y corrientes" que no son los correspondientes al caso ${ }^{44}$.

\footnotetext{
${ }^{42}$ CARBONE, Carlos Alberto. Cargas probatorias dinámicas: una mirada al derecho comparado y novedosa ampliación de su campo de acción. In: PEYRANO, Jorge W. (Director); WHITE, Inés Lépori (Coordinadora). Cargas probatorias dinámicas. $1^{\mathrm{a}}$ ed. Santa Fe: Rubinzal-Culzoni, 2008. Cap. 12, p. 197-227. p. 141.

${ }^{43}$ WHITE, Inés Lépori. Cargas probatorias dinámicas. p. 60.

${ }^{44}$ PEYRANO, Jorge W. Nuevos liniamentos de las cargas probatorias dinámicas. In: PEYRANO, Jorge W. (Director); WHITE, Inés Lépori (Coordinadora). Cargas probatorias dinámicas. $1^{\mathrm{a}}$ ed. Santa Fe: Rubinzal-Culzoni, 2008. Cap. 2, p. 19-24. p. 24.
} 
Apesar de sua excepcionalidade e de seu surgimento atrelado aos casos de responsabilidade civil dos profissionais liberais, a teoria ganhou uma verdadeira força expansiva através do trabalho da jurisprudência argentina, que a vem aplicando em casos antes não imaginados, como, por exemplo, em ações de alimentos e ações anulatórias de negócios jurídicos. Jorge Peyrano, comentando o êxito da teoria que ajudou a formular, observa que nossos juízes, felizmente, se mostram cada vez mais inclinados a ponderar adequadamente as circunstâncias do caso concreto, apesar de nenhuma disposição legal thes prescrever expressamente esta tarefa ${ }^{45}$. Parece que a abstração da ciência processual, arduamente construída pela escola chiovendiana, vai, gradativamente, cedendo espaço para a realidade.

\subsection{A prova da melhor condição probatória da parte}

A teoria das cargas probatórias dinâmicas, como visto, tem especial aplicação naqueles casos em que há evidente desigualdade entre a possibilidade probatória das partes. Para equilibrá-la, o encargo probatório é atribuído à parte que se encontra em melhores condições de cumpri-lo. Surgem, dessa situação, duas indagações naturais: O que implica estar em melhores condições de produzir a prova? E qual o papel probatório que deve desempenhar a parte que não está em condições de produzi-la?

Sergio José Barberio, jurista argentino que se debruçou especificamente sobre estas duas indagações, afirma que a melhor condição probatória é evidenciada quando o sujeito, em virtude do papel que desempenhou no fato gerador da controvérsia, por estar de posse da coisa ou do instrumento probatório ou por ser o único que dispõe da prova, se encontra em posição

\footnotetext{
${ }^{45}$ PEYRANO, Jorge W; CHIAPPINI, Julio O. Liniamentos de las cargas probatorias "dinámicas". p. 17.
} 
privilegiada para revelar a verdade e seu dever de colaboração se acentua a ponto de atribuir-lhe um ônus probatório que, a princípio, não teria ${ }^{46}$. Mais a frente, lembra que esta posição privilegiada também pode estar fundada em razões profissionais, técnicas, econômicas ou jurídicas, conforme já se manifestou a Corte Suprema de Justiça da Nação Argentina ${ }^{47}$.

Observa o autor que, muitas vezes, a posição dominante frente aos meios de prova surgirá evidenciada dos próprios documentos constantes dos autos, da própria natureza da controvérsia ou das próprias afirmações dos sujeitos processuais ${ }^{48}$. Adverte, entretanto, que esta constatação nem sempre será tão simples assim. Nesses casos, a melhor condição probatória da parte deverá ser demonstrada e sua prova recairá sobre a parte cuja dinamização beneficiará $^{49}$.

A aplicação prática da distribuição dinâmica do ônus probatório implica no aumento do encargo probatório de uma das partes e, em contrapartida, no natural abrandamento do onus probandi da outra. Por essa razão, afirma Sergio José Barberio que aquele que pretende o abrandamento de seu encargo deve, ainda que indiretamente, demonstrar que a parte contrária está ou estava em melhores condições de produzir a prova ${ }^{50}$. Fundamentando seu posicionamento, o autor afirma que o enfoque dinâmico do ônus da prova e o princípio da solidariedade não são equiparáveis a uma taxativa inversão do ônus da prova, como parte da jurisprudência argentina vinha empregando-os ${ }^{51}$.

\footnotetext{
${ }^{46}$ BARBERIO, Sergio José. ¿Qué debe probar el que no puede probar?. In: PEYRANO, Jorge W. (Director); WHITE, Inés Lépori (Coordinadora). Cargas probatorias dinámicas. $1^{\mathrm{a}}$ ed. Santa Fe: Rubinzal-Culzoni, 2008. Cap. 6, p. 99-105. p. 101.

${ }^{47}$ Ibid. p. 101.

48 Ibid. p. 102.

${ }^{49}$ Ibid. p. 102.

${ }^{50}$ Ibid. p. 102.

${ }^{51}$ Nesse sentido, discorre Eduardo Cambi: “Com efeito, não há na distribuição dinâmica do ônus da prova uma inversão, nos moldes previstos no art. $6^{\circ}$, inc. VIII, do CDC, porque só se poderia falar em inversão caso o ônus fosse estabelecido prévia e abstratamente. Não é o que acontece com a técnica da distribuição dinâmica, quando o magistrado, avaliando as peculiaridades do caso concreto, com base
} 
Lembra o autor que "alivianar, aligerar o favorecer no implica derechamente eximir o liberar de toda la carga" ${ }^{, 52}$.

Poder-se-ia argumentar, diante desta situação, que a existência da regra dinâmica de distribuição do ônus da prova pouco contribuiria para o processo civil, pois, em muitas ocasiões, a prova da melhor condição probatória da parte também se mostraria extremamente difícil e a parte hipossuficiente permaneceria diante da necessidade de produzir uma probatio diabolica. No entanto, é preciso reconhecer que a demonstração exigida para a aplicação da teoria é muito mais superficial e simples do que a prova exigida para a demonstração dos fatos controvertidos. Dessa forma, frente à dificuldade de se demonstrar a melhor condição probatória da parte contrária, poderá o litigante, por exemplo, se valer da produção de provas indiciárias, as quais deverão ser cuidadosamente valoradas pelo magistrado, ao lado da própria conduta processual das partes.

O que é importante extrair destas reflexões é que a distribuição dinâmica do ônus da prova não deve ser utilizada indiscriminadamente para acentuar o encargo probatório de um dos litigantes, sem que se exija qualquer esforço probatório da parte beneficiada. Se o princípio da solidariedade e o dever de cooperação "obrigam" que a parte em melhores condições fáticas produza a prova do fato controvertido, os mesmos fundamentos "exigem" que a parte em situação de inferioridade desenvolva atividade probatória que, ainda que insuficiente, demonstre sua intenção de colaborar ${ }^{53}$. Do contrário, observa demandante e pelo demandado." (CAMBI, Eduardo. A prova civil.p. 341.)

${ }_{53}$ BARBERIO, Sergio José. ¿Qué debe probar el que no puede probar?. p. 102.

${ }^{53}$ A parte beneficiada deve demonstrar que forneceu todos os elementos probatórios de que dispunha e que eventual deficiência do conjunto probatório advém de situações completamente alheias à sua vontade. 
Sergio José Barberio, "la comidad o el refugio en el esquema estático que objetamos no habrá hecho más que cambiar de manos" ${ }^{\text {" }}$.

Se, chegado ao final do processo, não existirem provas suficientes para formar a convicção do magistrado acerca dos fatos controvertidos, nem tampouco elementos suficientes que demonstrem a facilidade de uma das partes de produzir a prova, diante da impossibilidade da outra em produzi-la, dificilmente poderá se falar na aplicação da teoria das cargas probatórias dinâmicas. Portanto, é de crucial importância a atividade probatória desenvolvida pela parte em situação de inferioridade, a fim de demonstrar - ou corroborar, quando esta é de fácil constatação - a desigualdade fática em que os litigantes se encontram, bem como seu empenho em cooperar na reconstrução dos fatos.

\subsection{A valoração da prova produzida pela parte em melhor condição probatória}

A teoria das cargas probatórias dinâmicas, assim como qualquer outra criação que incida diretamente sobre a realidade e a conduta humana, não pode pecar pela subestimação da inteligência do próprio homem que, infelizmente, é utilizada com freqüência para satisfação exclusiva do sujeito, a despeito de qualquer norma de conduta social (sem referência exclusiva às normas de direito positivo) ou noção de solidariedade. Ou seja, a teoria não pode ignorar o fato de que a parte que está em melhores condições fáticas de produzir a prova também está, naturalmente, em melhores condições de desvirtuá-la em seu próprio benefício. O princípio da solidariedade e o dever de cooperação, brilhantemente revigorados pela obra de Jorge Peyrano e Augusto Morello, não

\footnotetext{
${ }^{54}$ BARBERIO, Sergio José. ¿Qué debe probar el que no puede probar? p. 103.
} 
podem sofrer um tratamento entusiasticamente ingênuo, quiçá romântico, como se a adequada reconstrução dos fatos controvertidos fosse o objetivo comum dos litigantes. É necessário reconhecer que, no processo civil, os interesses particulares são, salvo raras exceções, diametralmente opostos e a busca desenfreada pela satisfação destes interesses pode conduzir o sujeito a uma manipulação dos elementos probatórios.

A doutrina argentina, muito embora reconheça esta fragilidade da teoria, dedicou muito pouca atenção ao problema, limitando-se a afirmar que o juiz deve ser extremamente cuidadoso e rigoroso no momento de valorar a prova produzida pela parte em melhores condições fáticas ${ }^{55}$, reforçando a importância do senso comum e das máximas de experiência na fase de valoração. No presente estudo, entretanto, ousar-se-á ir um pouco mais além desta conclusão da doutrina argentina que, apesar de representar uma válida diretriz valorativa ao magistrado, deixou de lado outros fatores importantes.

Em primeiro lugar, é necessário reconhecer que não há uma solução adequada para afastar completamente a possibilidade de uma decisão fundada em provas manipuladas pelas partes, até porque esta possibilidade não é um privilégio do ônus dinâmico e também está presente quando incidem as regras tradicionais de repartição do ônus da prova. No entanto, é evidente que, quando uma das partes goza de privilegiada posição frente aos meios de prova, esta possibilidade se acentua e é necessário que se estabeleçam meios de atenuá-la.

O primeiro deles é a atividade probatória subsidiária desenvolvida pela parte que não está em condições de produzir a prova dos fatos controvertidos, comentada no tópico anterior. A aplicação da teoria das cargas probatórias

\footnotetext{
${ }^{55}$ PEYRANO, Jorge W. Nuevos liniamentos de las cargas probatorias dinámicas. p. 23.
} 
dinâmicas, conforme exaustivamente explicitado, pressupõe uma desigualdade de fato entre as partes, de modo que a uma delas é impossível a produção da prova e à outra é plenamente possível. Portanto, a parte em situação privilegiada pode, no afã de demonstrar que também não está em condições de suportar o encargo e, conseqüentemente, afastar a incidência do ônus dinâmico, destruir ou desaparecer com as provas dos fatos. Nesses casos, somente a atividade probatória desenvolvida pela parte hipossuficiente poderá atenuar os riscos advindos desta atitude lesiva da parte contrária, pois é a maneira mais eficaz de influir no convencimento do magistrado acerca da possibilidade probatória de ambas as partes.

Por outro lado, a parte hipossuficiente também poderá fornecer provas que, apesar de não serem capazes de provar os fatos controvertidos, demonstrem que as provas produzidas pela parte adversária foram alvos de manipulações fraudulentas, sendo imprestáveis para embasar uma decisão judicial. Mais uma vez, fica evidente a importância da atividade probatória desenvolvida pela parte em situação de inferioridade, que jamais poderia se acomodar no processo.

O segundo meio de atenuar a possibilidade de uma decisão judicial baseada em provas desvirtuadas é o fortalecimento da iniciativa probatória do órgão judicial, principalmente quando a reconstrução dos fatos depende de conhecimentos profissionais ou técnicos, pois, nesses casos, o magistrado e a parte hipossuficiente, por não gozarem dos conhecimentos específicos da parte em situação privilegiada, podem facilmente ficar a mercê de suas conclusões, algo muito semelhante, guardadas as devidas proporções, com o que ocorre 
hoje em dia com as conclusões apresentadas pelos peritos, no processo civil brasileiro $^{56}$.

Nessas situações, para que se evite que a parte induza o magistrado a um resultado que lhe privilegie, é importante que o órgão judicial conte sempre com a assistência da perícia técnica, a qual deverá acompanhar de perto os resultados obtidos no processo de conhecimento ${ }^{57}$. Por exemplo, voltando ao caso de responsabilidade civil por erro médico, é fundamental que a reconstrução dos fatos ocorridos na privacidade da sala de cirurgia, possível somente mediante a cooperação do cirurgião, seja acompanhada por um profissional de confiança do juízo, asseguradamente imparcial e que detenha a mesma capacitação técnica do réu, para que não haja qualquer tipo de indução no resultado por parte do demandado.

A iniciativa probatória do órgão judicial é digna, ainda, de uma última nota. Se a prova do fato controvertido puder ser realizada mediante a simples atividade probatória do juiz, não há porque se falar na aplicação da teoria das cargas probatórias dinâmicas, quando a diligência será determinada de ofício pelo próprio magistrado, com base nos poderes de instrução conferidos pelo

\footnotetext{
${ }^{56}$ Sobre o problema atual da perícia no Brasil, destaca-se a seguinte passagem de Leonardo Greco: "O temor dos advogados em relação à ditadura do perito se concretizou. No momento em que o juiz escolhe o perito, a confiança que nele deposita pode implicar com freqüência em verdadeira delegação da jurisdição sobre a matéria técnico-científica. Pouca ou nenhuma influência na decisão judicial têm os pareceres críticos dos assistente-técnicos das partes, agora oficialmente parciais, tendenciosos e apresentados somente depois que o perito do juízo já apresentou as suas conclusões. O próprio juiz se torna presa das conclusões da perícia, pela impossibilidade de controle de sua credibilidade, o que, segundo RICCI, acaba por transformar a perícia numa prova legal, que se sobrepõe à própria livre convicção." (GRECO, Leonardo. A Prova no Processo Civil: do Código de 1973 ao Novo Código Civil. In: GRECO, Leonardo; NETTO, Fernando Gama de Miranda. Direito Processual e Direitos Fundamentais. Rio de Janeiro: Lumen Juris, 2005. Cap. 5, p. 95-124. p. 118.)

${ }^{57}$ Cfr.: CÂMARA, Alexandre Freitas. Doenças preexistentes e ônus da prova: o problema da prova diabólica e uma possível solução. Revista Dialética de Direito Processual, São Paulo, n. 31, p. 9-19, out. 2005. Mensal.
} 
ordenamento jurídico $^{58}$. Esta constatação, no entanto, não reduz a importância da teoria, uma vez que, conforme observa Luiz Guilherme Marinoni, a atuação do juiz, ainda que bem vinda, não pode ser encarada como um remédio milagroso, pois a possibilidade de se produzir provas de ofício é restrita a casos muito específicos, sendo praticamente limitada às provas periciais, tendo em vista que ao juiz é quase impossível conhecer a existência de documentos ou testemunhas que possam servir para esclarecer os fatos controvertidos ${ }^{59}$.

\subsection{A nova Ley de Enjuiciamiento Civil espanhola}

Antes de finalizar este capítulo inteiramente dedicado à análise da teoria das cargas probatórias dinâmicas, é imprescindível que se comente, ainda que de forma abreviada, a sua definitiva consagração legislativa na nova Ley de Enjuiciamento Civil espanhola, promulgada em 7 de janeiro de 2000.

A legislação processual espanhola, salvo pontuais reformas, permanecia engessada desde 1881, e, evidentemente, não refletia mais as conquistas da doutrina processual moderna. Há anos aclamava-se por uma reforma integral que pudesse atualizá-la definitivamente, conferindo eficácia aos novos paradigmas do processo civil, dentre eles o da efetividade e da duração razoável do processo. Impregnado deste espírito reformador, o legislador espanhol se empenhou na tarefa de elaborar uma legislação processual de vanguarda que refletisse com exatidão os anseios de seu tempo.

\footnotetext{
58 No Brasil, o art. 130 do CPC dispõe: Caberá ao juiz, de ofício ou a requerimento da parte, determinar as provas necessárias à instrução do processo, indeferindo as diligências inúteis ou meramente protelatórias.

59 MARINONI, Luiz Guilherme. A questão do convencimento judicial. Disponível em: $<$ http://www.professormarinoni.com.br/principal/home/?pg=5\&\&\&\&sistema=conteudoslartigos\&cod_ categoria=artigos $>$. Acesso em: 21 abr. 2009.
} 
O primeiro anteprojeto da Ley de Enjuiciamento Civil, todavia, optou por consagrar expressamente as regras de distribuição do ônus probatório, seguindo a teoria clássica de Giuseppe Chiovenda, sem atentar para qualquer espécie de flexibilização diante das circunstâncias do caso concreto. Determinava, cegamente, que ao autor cabia a prova dos fatos constitutivos de seu direito e ao réu a prova dos fatos extintivos, impeditivos ou modificativos do direito do autor. Com isso, ignorava os avanços da doutrina processual e, acima de tudo, uma realidade: os juízes espanhóis já vinham, há anos, flexibilizando as tradicionais regras de repartição do encargo probatório, valendo-se do critério da disponibilidade e da facilidade, para atribuir, com base na proximidade real das partes em relação aos meios de prova, o onus probandi.

Diante disso, inúmeras críticas foram formuladas ao anteprojeto pela doutrina e pelos próprios membros do Poder Judiciário, o que culminou na apresentação do Informe al Anteprojecto de Ley de Enjuiciamento Civil, aprovado pelo Pleno del Consejo General del Poder Judicial, cuja conclusão demonstra claramente o descontentamento do judiciário espanhol com o tratamento dispensado às regras de repartição do ônus da prova:

(...) Sin embargo, además de lo que se destaca en el apartado anterior, el precepto sigue siendo una mera expresión del clásico aforismo ei incumbit probatio qui affirmat, non qui negat, sin que se incluyan en él los aspectos más relevantes de la carga de la prueba, de la lealtad y buena fé procesal, de la distribución de la carga en función de la proximidad o dominio del hecho por cada una de las partes ${ }^{60}$.

Frente à enxurrada de críticas, o Poder Legislativo espanhol reformulou o projeto de lei para incluir expressamente a possibilidade de flexibilização do ônus probatório diante das circunstâncias do caso concreto, levando-se em

\footnotetext{
${ }^{60}$ PEYRANO, Marcos L. La teoría de las “cargas probatorias dinámicas" en la flamante Ley de Enjuiciamento Civil Española (Ley 1/2000). In: PEYRANO, Jorge W. (Director); WHITE, Inés Lépori (Coordinadora). Cargas probatorias dinámicas. $1^{a}$ ed. Santa Fe: Rubinzal-Culzoni, 2008. Cap. 11, p. 179-193. p. 189.
} 
conta a disponibilidade e a facilidade probatória das partes ${ }^{61}$. O texto definitivo do artigo 217 da nova Ley de Enjuiciamento Civil espanhola (Lei 1/2000) assim dispõe:

Artículo 217. Carga de la prueba.

1. Cuando, al tiempo de dictar sentencia o resolución semejante, el tribunal considerase dudosos unos hechos relevantes para la decisión, desestimará las pretensiones del actor o del reconviniente, o las del demandado o reconvenido, según corresponda a unos u otros la carga de probar los hechos que permanezcan inciertos y fundamenten las pretensiones.

2. Corresponde al actor y al demandado reconviniente la carga de probar la certeza de los hechos de los que ordinariamente se desprenda, según las normas jurídicas a ellos aplicables, el efecto jurídico correspondiente a las pretensiones de la demanda y de la reconvención.

3. Incumbe al demandado y al actor reconvenido la carga de probar los hechos que, conforme a las normas que les sean aplicables, impidan, extingan o enerven la eficacia jurídica de los hechos a que se refiere el apartado anterior.

4. En los procesos sobre competencia desleal y sobre publicidad ilícita corresponderá al demandado la carga de la prueba de la exactitud y veracidad de las indicaciones y manifestaciones realizadas y de los datos materiales que la publicidad exprese, respectivamente.

5. De acuerdo con las leyes procesales, en aquellos procedimientos en los que las alegaciones de la parte actora se fundamenten en actuaciones discriminatorias por razón del sexo, corresponderá al demandado probar la ausencia de discriminación en las medidas adoptadas y de su proporcionalidad.

A los efectos de lo dispuesto en el párrafo anterior, el órgano judicial, a instancia de parte, podrá recabar, si lo estimase útil y pertinente, informe o dictamen de los organismos públicos competentes.

6. Las normas contenidas en los apartados precedentes se aplicarán siempre que una disposición legal expresa no distribuya con criterios especiales la carga de probar los hechos relevantes.

7. Para la aplicación de lo dispuesto en los apartados anteriores de este artículo el tribunal deberá tener presente la disponibilidad y facilidad probatoria que corresponde a cada una de las partes del litigio. ${ }^{62}$

De início, o artigo define as regras gerais de repartição do esforço probatório, necessariamente ligadas à posição processual das partes e à natureza do fato probando (itens 1, 2 e 3), para, em seguida, prever expressamente a possibilidade de sua flexibilização e/ou deslocamento

\footnotetext{
${ }^{61}$ Um dado curioso que demonstra o espírito do legislador espanhol de atender aos apelos doutrinários e jurisprudenciais é a própria estruturação da nova legislação, muito semelhante a um manual de direito processual.

62 ESPANHA. Ley de Enjuiciamento Civil. <http://noticias.juridicas.com/base_datos/Privado/112000.html> Acesso em 02 de mai. de 2009.
} 
dependendo (i) da natureza de determinadas controvérsias (itens 4 e 5$)^{63}$, (ii) de expressa previsão legal (item 6) ou (iii) das reais condições fáticas das partes "disponibilidad y facilidad" - para produzir a prova dos fatos controvertidos (item 7).

Dessa forma, ao definir que o juiz deve levar em consideração a real proximidade das partes em relação aos meios de prova no momento de aplicar as regras de distribuição do onus probandi, a nova legislação processual espanhola consagra o ideário da teoria das cargas probatórias dinâmicas, ainda que sob diferente denominação ${ }^{6465}$. Deixa claro, com isso, que a preocupação com a revisão das clássicas regras de repartição do encargo probatório é corrente nos países de tradição processual romanista, especialmente naqueles em que o comprometimento com a tutela justa e efetiva do direito material não se limita a mera proclamação principiológica.

\footnotetext{
63 Algo muito próximo do que nosso Código de Defesa do Consumidor determina em casos de publicidade enganosa ou abusiva (art. 38).

${ }^{64}$ Antes mesmo de sua consagração legislativa, os juízes espanhóis costumavam adotar a teoria sob a alcunha de princípio da facilidade probatória.

${ }^{65}$ Outro dado digno de nota é que estas regras de repartição do onus probandi não foram incluídas no capítulo destinado ao procedimento probatório, mas sim no capítulo que trata dos requisitos da sentença, o que nos leva a crer que o legislador espanhol, encerrando com a longa discussão doutrinária acerca do momento adequado para a repartição do ônus da prova, definiu que o mesmo deve ser feito por ocasião da sentença de mérito. No presente estudo, esta discussão será abordada mais a frente, quando serão analisadas as possibilidades de aplicação da teoria das cargas probatórias dinâmicas no Brasil.
} 


\section{DISTRIBUIÇÃO DINÂMICA DO ÔNUS DA PROVA NO PROCESSO CIVIL BRASILEIRO - APLICABILIDADE}

\subsection{Considerações iniciais}

Analisados, frente a frente, o enfoque estático e o enfoque dinâmico da distribuição do ônus da prova, surge o seguinte questionamento: a aplicação da teoria das cargas probatórias dinâmicas é legítima no processo civil brasileiro?

A primeira grande dificuldade encontrada para fornecer uma resposta adequada para esta questão é, por mais contraditório que possa parecer, a escassez de trabalhos escritos que refutem abertamente a aplicabilidade da teoria $^{66}$. E essa constatação, incrivelmente, não se aplica de forma exclusiva ao Brasil. O próprio Peyrano, ao escrever sobre a natural resistência que a teoria precisava estar preparada para encarar, insiste que são poucos os trabalhos difundidos no meio acadêmico argentino que apresentam óbices bem fundamentados à teoria das cargas probatórias dinâmicas ${ }^{67}$. De todos os argumentos desfavoráveis, Jorge Peyrano destaca apenas dois: o primeiro - e também o mais óbvio - consiste em afirmar que não há previsão legal que

\footnotetext{
${ }^{66}$ No Brasil já existem inúmeros trabalhos dedicados à teoria das cargas probatórias dinâmicas, porém, nenhum abertamente contrário à sua aplicabilidade; muito pelo contrário, tanto a doutrina brasileira quanto nossos juízes têm recebido a teoria com grande entusiasmo. Dos trabalhos realizados, indica-se as seguintes leituras: (i) SOUZA, Wilson Alves de. Ônus da Prova: considerações sobre a doutrina das cargas probatórias dinâmicas. Revista Jurídica dos Formandos em Direito da UFBA, Salvador, v. 6, p.234-260, fev. 1999; (ii) DALL'AGNOL JR., Antonio Janyr. Distribuição Dinâmica dos Ônus Probatórios. Revista dos Tribunais, São Paulo, v. 788, p.93-107, jun. 2001. Mensal; (iii) KNIJNIK, Danilo. As (perigosíssimas) doutrinas do "ônus dinâmico da prova" e da "situação de senso comum" como instrumentos para assegurar o acesso à justiça e superar a probatio diabolica. In: FUX, Luiz; NERY JR., Nelson; WAMBIER, Teresa Arruda Alvim. Processo e Constituição: estudos em homenagem ao Professor José Carlos Barbosa Moreira. São Paulo: Revista dos Tribunais, 2006. Cap. 77, p. 942-958; (iv) CÂMARA, Alexandre Freitas. Doenças preexistentes e ônus da prova: o problema da prova diabólica e uma possível solução. Revista Dialética de Direito Processual, São Paulo, n. 31, p. 9-19, out. 2005. Mensal; (v) ZANFERDINI, Flávia de Almeida Montigelli; GOMES, Alexandre Gir. Cargas probatórias dinâmicas no processo civil brasileiro. Revista Dialética de Direito Processual, São Paulo, n. 69, p.17-35, dez. 2008. Mensal, e (vi) CAMBI, Eduardo. A prova civil: admissibilidade e relevância. São Paulo: Revista dos Tribunais, 2006. p. 340-346.

${ }^{67}$ PEYRANO, Jorge W. La doctrina de las cargas probatorias dinámicas y la máquina de impedir en materia jurídica.. In: PEYRANO, Jorge W. (Director); WHITE, Inés Lépori (Coordinadora). Cargas probatorias dinámicas. $1^{\text {a }}$ ed. Santa Fe: Rubinzal-Culzoni, 2008. Cap. 5, p. 75-98. p. 87.
} 
permita a aplicação da teoria; o segundo - e que, de acordo com Peyrano, representa uma "línea de impugnación (...) más seria"68 - consiste em afirmar que a aplicação de ofício da teoria criaria uma insustentável imprevisibilidade procedimental, pois surpreenderia as partes que estavam confiantes na incidência da norma legal de repartição do encargo probatório, o que atentaria contra o primado do devido processo legal ${ }^{69}$.

Partindo desses óbices apontados pela doutrina argentina, posto que se enquadram perfeitamente no rol de óbices que a própria doutrina brasileira poderia formular, sobretudo em razão da similitude da tradição processual de ambos os países, buscar-se-á, neste capítulo, uma resposta para a pergunta formulada acima: seria legítima a aplicação da teoria das cargas probatórias dinâmicas no Brasil?

\subsection{Ausência de expressa previsão legal}

Como se sabe, o Código de Processo Civil brasileiro, ao dispor sobre a repartição do encargo probatório, adotou expressamente a regra clássica, conforme dispositivo do art. 333:

Art. 333. O ônus da prova incumbe:

I - ao autor, quanto ao fato constitutivo do seu direito;

II - ao réu, quanto à existência de fato impeditivo, modificativo ou extintivo do direito do autor.

\footnotetext{
${ }^{68}$ PEYRANO, Jorge W. La doctrina de las cargas probatorias dinámicas y la máquina de impedir en materia jurídica. p. 88.

${ }^{69}$ Esses são os argumentos defendidos pelo processualista argentino Maximiliano García Grande, um dos maiores críticos da teoria, representante da doutrina garantista do direito processual civil. Esta doutrina, que conta com um número razoável de adeptos na Argentina, contesta, por exemplo, toda e qualquer forma de ativismo judicial e procedimentos de cognição sumária, indo em direção contrária à maioria esmagadora da doutrina processual moderna. Cfr.: GRANDE, Maximiliano García. Cargas probatorias dinámicas: ni nuevas, ni argentinas, ni aplicables. Disponível em: <http://www.ederecho.org.ar/congresoprocesal/Cargas\%20Probatorias\%20Din\%E1micas\%20_Grande_pdf> Acesso em: 02 mai. 2009.
} 
Salvo pontuais exceções legalmente previstas, como a regra de inversão do ônus da prova nas relações de consumo $^{70}$ e as próprias convenções particulares $^{71}$, esta é a norma que rege os litígios deduzidos no processo civil brasileiro, sem que haja qualquer previsão legal que possibilite ao juiz modificá-la diante das circunstâncias do caso concreto.

Portanto, quando se investiga a possibilidade de aplicação da teoria das cargas probatórias dinâmicas no Brasil, uma primeira resposta surge, quase que intuitivamente, no sentido de refutá-la. Ora, uma vez que existe norma expressa versando sobre a distribuição do onus probandi e que, à primeira vista, não exige um processo de racionalização mais sofisticado para ser interpretada, caberia ao magistrado, tão-somente, aplicá-la pelo mecanismo tradicional da subsunção. Ou seja, tendo o magistrado chegado ao final do processo sem formar sua convicção acerca dos fatos controvertidos, restaria a ele observar qual dos litigantes deve suportar a insuficiência da instrução probatória (de acordo com a hipótese abstratamente prevista), para concluir pela aplicação da norma do art. 333 como regra de julgamento.

Argumentar-se-ia, nessa linha de raciocínio, que qualquer modificação judicial desta regra de repartição do encargo probatório colocaria em cheque valores essenciais prestigiados pelo ordenamento jurídico, como a segurança jurídica, a paz e a igualdade. O Poder Legislativo, ao optar pela edição de uma regra e, dessa forma, pré-decidir o meio de exercício do poder estatal, visa afastar a incerteza e a controvérsia moral que surgiriam caso esta regra não

\footnotetext{
${ }^{70}$ O Código de Defesa do Consumidor consagrou, dentre os direitos básicos do consumidor, a facilitação da defesa de seus direitos, inclusive com a inversão do ônus da prova, a seu favor, no processo civil, quando, a critério do juiz, for verossímil a alegação ou quando for ele hipossuficiente, segundo as regras ordinárias de experiências (Art. $6^{\circ}$, inc. VIII).

${ }^{71} \mathrm{O}$ próprio art. 333 do $\mathrm{CPC}$, no seu parágrafo único, admite as convenções particulares sobre a distribuição do ônus da prova.
} 
fosse editada ${ }^{72}$. Conseqüentemente, argumentar-se-ia, qualquer decisão que superasse a aplicação desta regra com base nas particularidades do caso concreto geraria uma insustentável situação de incerteza, indo em direção completamente contrária à finalidade da própria elaboração da regra e comprometendo a previsibilidade do próprio ordenamento jurídico. Com isso, afirmar-se-ia, como faz Maximiliano García Grande, "los ciudadanos no sabrían a que leyes atenerse y no habría seguridad jurídica."73 74

Além disso, poder-se-ia afirmar que o papel do magistrado é velar pela aplicação das normas legais, conforme prevê expressamente o art. 126 do $\mathrm{CPC}^{75}$, o que limita sua atuação à estrita descrição da lei e à busca da vontade do legislador, independentemente de seu conteúdo. A aplicação da teoria das cargas probatórias dinâmicas, portanto, excederia a função do magistrado e adentraria na nebulosa seara da arbitrariedade judicial, impregnada de subjetividades e juízos de valores, comprometendo, em última análise, o tratamento igualitário que o Direito deve dispensar a todos ${ }^{76}$.

\footnotetext{
72 ÁVILA, Humberto. Teoria dos princípios: da definição à aplicação dos princípios jurídicos. $9^{\mathrm{a}}$ ed. São Paulo: Malheiros Editores, 2009. 113 p.

${ }^{73}$ GRANDE, Maximiliano García. Cargas probatorias dinámicas: ni nuevas, ni argentinas, ni aplicables. $\quad$ Disponível em: <http://www.ederecho.org.ar/congresoprocesal/Cargas\%20Probatorias\%20Din\%E1micas\%20_Grande_pdf> Acesso em: 02 mai. 2009.

${ }^{74}$ Nesse ponto, antes de qualquer análise mais profunda, é interessante fazer um questionamento: qual é a espécie de segurança jurídica cultivada por um ordenamento que, pretensamente comprometido com a efetiva proteção dos direitos fundamentais e com a promoção da paz social, assegura um direito no plano material e, no momento de sua violação (ou ameaça de), nega-lhe tutela, simplesmente porque seu titular não dispõe dos meios probatórios necessários para demonstrar seu fato constitutivo, que se encontram ao alcance da parte contrária ou de terceiros?

75 Art. 126. O juiz não se exime de sentenciar ou despachar alegando lacuna ou obscuridade da lei. No julgamento da lide caber-lhe-á aplicar as normas legais; não as havendo, recorrerá à analogia, aos costumes e aos princípios gerais de direito.

${ }^{76}$ Nesse sentido, dispõe Maximiliano Garcia Grande: "Siendo la justicia el reflejo más cercano a las soluciones de las necesidades sociales en um momento histórico dado, debe ésta emanar de um organismo parlamentario, representativo de la Sociedad misma y de la gran mayoría de los sectores; no de una sola persona, por más conocimiento jurídico que posea, porque es más evidente el subjetivismo y la imperfección humana cuando el emisor es una sola persona y no cuando proviene de órganos deliberativos." (GRANDE, Maximiliano García. Cargas probatorias dinámicas: ni nuevas, ni argentinas, ni aplicables. Disponível em: <http://www.e-
} 
Entretanto, muito embora não se negue a importância da segurança jurídica e do dever do juiz de submissão à lei, é preciso reconhecer que a linha de raciocínio acima descrita está visivelmente impregnada pelos valores liberais e pelas concepções do positivismo jurídico do séc. XIX.

A busca a todo custo por um direito previsível ou pela chamada "certeza do direito" é uma pretensão típica do Estado Liberal. Pensava-se que para garantir a liberdade e a igualdade dos cidadãos, valores máximos da filosofia liberal, era necessário a edição de leis que guardassem as características da generalidade e da abstração. Ou seja, a norma não poderia levar em consideração qualquer setor específico da sociedade ou ser elaborada para incidir sobre uma hipótese determinada. A generalidade, segundo a constatação de Luiz Guilherme Marinoni, era pensada como garantia da imparcialidade do poder frente aos cidadãos e a abstração como garantia da estabilidade do ordenamento jurídico ${ }^{77}$. Dessa forma, a segurança jurídica, aqui compreendida como fruto da previsibilidade na aplicação das normas de determinado ordenamento $^{78}$, figura como um elemento indispensável para esta equação. Isso porque "de nada adiantaria uma lei marcada pela generalidade e pela abstração se o juiz pudesse conformá-la às diferentes situações concretas"79. Assim, segundo os valores liberais, qualquer atuação do juiz que não se limitasse à

derecho.org.ar/congresoprocesal/Cargas\%20Probatorias\%20Din\%E1micas\%20_Grande_pdf> Acesso em: 02 mai. 2009)

${ }^{77}$ MARINONI, Luiz Guilherme. Teoria geral do processo. p. 29.

${ }^{78}$ Apesar do tratamento ora restritivo, não se pode esquecer que, "no seu desenvolvimento doutrinário e jurisprudencial, a expressão segurança jurídica passou a designar um conjunto abrangente de idéias e conteúdos, que incluem: 1. a existência de instituições estatais dotadas de poder e garantias, assim como sujeitas ao princípio da legalidade; 2. a confiança nos atos do Poder Público, que deverão regerse pela boa-fé e pela razoabilidade; 3. a estabilidade das relações jurídicas, manifestada na durabilidade das normas, na anterioridade das leis em relação aos fatos sobre os quais incidem e na conservação de direitos em face da lei nova. 4. a previsibilidade dos comportamentos, tanto os que devem ser seguidos como os que devem ser suportados; 5. a igualdade na lei e perante a lei, inclusive com soluções isonômicas para situações idênticas ou próximas." (BARROSO, Luis Roberto. A segurança jurídica na era da velocidade e do pragmatismo. In: BARROSO, Luis Roberto. Temas de direito constitucional. $2^{\mathrm{a}}$ ed. Rio de Janeiro: Renovar, 2002. Cap. 2, p. 49-73. p. 51).

${ }^{79}$ MARINONI, Luiz Guilherme. op. cit. p. 30. 
mera descrição da lei obscureceria a previsibilidade e a certeza do direito, ferindo a própria liberdade política dos cidadãos. Nesse sentido, discorria Montesquieu, já em 1748, na sua célebre obra Do espírito das leis:

Mas, se os tribunais não devem ser fixos, os julgamentos devem sê-lo a tal ponto que nunca sejam mais do que um texto preciso da lei. Se fossem uma opinião particular do juiz, viveríamos em sociedade sem saber precisamente os compromissos ali assumidos ${ }^{80}$.

Naturalmente, essas idéias remetem às concepções da sistematicidade e da plenitude do direito, baseadas na crença de que as leis e os Códigos elaborados eram de tal forma completos e coerentes, que qualquer conflito poderia ser solucionado a partir da simples aplicação de normas positivadas. Essas concepções, frutos naturais do "império da lei" instituído pelo pensamento liberal, ganharam contornos científicos através do desenvolvimento do positivismo jurídico do séc. XIX que, de acordo com a lição de Luis Roberto Barroso, consistiu na "importação do positivismo filosófico para o mundo do Direito, na pretensão de criar-se uma ciência jurídica com características análogas às ciências exatas e naturais." ${ }^{\text {(1 }}$

Ao sair em busca da "objetividade científica, com ênfase na realidade observável e não na especulação filosófica", o positivismo jurídico "apartou o Direito da moral e dos valores transcendentes" 82 . Completamente imersos no pensamento cientificista de sua época, os positivistas passaram a encarar o

\footnotetext{
${ }^{80}$ MONTESQUIEU, Charles de. Do espírito das leis. Disponível em: <http://www.esnips.com> Acesso em: 10 mai. 2009.

${ }^{81}$ BARROSO, Luis Roberto. Fundamentos teóricos e filosóficos do Direito Constitucional brasileiro. Disponível em: <http://jus2.uol.com.br/doutrina/texto.asp?id=3208>. Acesso em: 16 mai. 2009. Sobre o positivismo filosófico, discorre o autor: "O positivismo filosófico foi fruto de uma idealização do conhecimento científico, uma crença romântica e onipotente de que os múltiplos domínios da indagação e da atividade intelectual pudessem ser regidos por leis naturais, invariáveis, independentes da vontade e da ação humana. $O$ homem chegara à sua maioridade racional e tudo passara a ser ciência: o único conhecimento válido, a única moral, até mesmo a única religião. O universo, conforme divulgado por Galileu, teria uma linguagem matemática, integrando-se a um sistema de leis a serem descobertas, e os métodos válidos nas ciências da natureza deviam ser estendidos às ciências sociais."

${ }^{82}$ BARROSO, Luis Roberto. Fundamentos teóricos e filosóficos do Direito Constitucional brasileiro. Disponível em: <http://jus2.uol.com.br/doutrina/texto.asp?id=3208>. Acesso em: 16 mai. 2009.
} 
Direito meramente como um fato, apartado de qualquer análise valorativa ${ }^{83}$. Nas palavras de Noberto Bobbio:

O direito é considerado como um conjunto de fatos, de fenômenos ou de dados sociais em tudo análogos àqueles do mundo natural; o jurista, portanto, deve estudar o direito do mesmo modo que o cientista estuda a realidade natural, isto é, abstendose absolutamente de formular juízos de valor. Na linguagem juspositivista o termo direito é então absolutamente avalorativo, isto é, privado de qualquer conotação valorativa ou ressonância emotiva; o direito é tal que prescinde do fato de ser bom ou mau, de ser um valor ou um desvalor ${ }^{84}$.

Como corolários desta forma de abordar e encarar o Direito estão, dentre outros cuja análise foge da proposta deste estudo, (i) o formalismo jurídico, pelo qual a validade de uma norma decorre exclusivamente do procedimento seguido para sua criação, independendo de seu conteúdo ${ }^{85}$, e (ii) a teoria da interpretação mecanicista ${ }^{86}$, na qual a atividade do jurista é predominantemente declarativa, consistente na aplicação asséptica de normas formalmente válidas. Com isso, percebe-se que o positivismo jurídico foi responsável por uma inconcebível simplificação das tarefas e das responsabilidades dos juízes (como também dos professores, advogados e juristas de uma forma geral ${ }^{87}$. Ao limitar sua atuação à mera reprodução da lei existente, o positivismo impede que o juiz tome uma posição frente à realidade, tornando-o completamente indiferente aos resultados injustos que a prática porventura possa revelar; ao restringir sua liberdade interpretativa e funcional, reduz também sua responsabilidade social, política, jurídica, econômica e humana.

\footnotetext{
83 "Ora, a característica fundamental da ciência consiste em sua avaloratividade, isto é, na distinção entre juízos de fato e juízos de valor e na rigorosa exclusão destes últimos do campo científico: a ciência consiste somente em juízos de fato." (BOBBIO, Noberto. O Positivismo Jurídico: Lições de filosofia do direito. São Paulo: Ícone, 1995. p. 135).

${ }^{84}$ BOBBIO, Noberto. O Positivismo Jurídico: Lições de filosofia do direito. São Paulo: Ícone, 1995. p. 131.

${ }^{85}$ BARROSO, Luis Roberto. Fundamentos teóricos e filosóficos do Direito Constitucional brasileiro. Disponível em: <http://jus2.uol.com.br/doutrina/texto.asp?id=3208>. Acesso em: 16 mai. 2009.

${ }^{86}$ BOBBIO, Noberto. op. cit. p. 133.

${ }^{87}$ MARINONI, Luiz Guilherme. Teoria geral do processo. p. 32.
} 
Portanto, quando se refuta a aplicabilidade da teoria das cargas probatórias dinâmicas no Brasil, sob o argumento de que já existe uma norma formalmente válida versando sobre a repartição do encargo probatório (no caso o dispositivo do art. 333 do CPC) e que a função do juiz é aplicá-la no caso concreto, deixa-se transparecer, além de uma preocupação tipicamente liberal, uma concepção de Direito visivelmente marcada pelos traços do positivismo jurídico. E não é preciso muito esforço para reconhecer que tanto o Estado Liberal Clássico quanto o positivismo jurídico representam paradigmas já superados pelo pensamento moderno ${ }^{88}$ :

Sem embargo da resistência filosófica de outros movimentos influentes nas primeiras décadas do século (referindo-se ao séc. XX), a decadência do positivismo é emblematicamente associada à derrota do fascismo na Itália e do nazismo na Alemanha. Esses movimentos políticos e militares ascenderam ao poder dentro do quadro de legalidade vigente e promoveram a barbárie em nome da lei. Os principais acusados de Nuremberg invocaram o cumprimento da lei e a obediência a ordens emanadas da autoridade competente. Ao fim da Segunda Guerra Mundial, a idéia de um ordenamento jurídico indiferentes a valores éticos e da lei como uma estrutura meramente formal, uma embalagem para qualquer produto, já não tinha mais aceitação no pensamento esclarecido ${ }^{89}$.

A partir da segunda metade do séc. XX, com os horrores da guerra ainda vivos na consciência e com o fortalecimento do discurso humanitário, surgiram inúmeras discussões e reflexões sobre a interpretação, a legitimidade e a função social do Direito. Se, por um lado, estava claro que a rígida separação entre o Direito e os valores éticos e morais tinha sido responsável pela legitimação de autoritarismos de matizes variados e não correspondia mais ao estágio do desenvolvimento civilizatório, por outro, era necessário reconhecer que o Direito já havia sido definitivamente impregnado pelo discurso científico

\footnotetext{
${ }^{88}$ Aliás, até mesmo as ciências exatas e naturais, cujos métodos foram incorporados pelo positivismo jurídico, passam por um momento de revisão e superação de seus próprios paradigmas, principalmente em função do desenvolvimento da física quântica e da ascensão do paradigma transdisciplinar e holístico. Cfr.: SANTOS, Boaventura de Souza. Um discurso sobre as ciências. $5^{\mathrm{a}}$ ed. São Paulo: Cortez, 2008. 92 p.

${ }^{89}$ BARROSO, Luis Roberto. Fundamentos teóricos e filosóficos do Direito Constitucional brasileiro. Disponível em: <http://jus2.uol.com.br/doutrina/texto.asp?id=3208>. Acesso em: 16 mai. 2009.
} 
e que o retorno puro e simples ao jusnaturalismo, com seus fundamentos vagos, abstratos ou metafísicos, não era exatamente o desejo de seus operadores $^{90}$.

É justamente nesse contexto que surge a moderna dogmática constitucional. Com o intuito de promover a adequada defesa dos cidadãos frente aos abusos que poderiam vir a ser cometidos pelo próprio Estado (ou por quaisquer detentores do poder em suas mais variadas manifestações) ${ }^{91}$ e permitir o controle da lei por órgãos diversos do Poder Legislativo, em especial o Judiciário, as modernas Constituições foram inundadas, explícita ou implicitamente, de valores éticos, morais e de justiça, materializados por uma série de princípios e regras fundamentais. Conforme observa Mauro Cappelletti, essa foi a primeira tentativa de se "positivar" algo que estivesse fora e acima da lei normal e de quem a elabora ${ }^{92}$.

Para poderem controlar a criação e a aplicação da lei, essas Constituições perderam quaisquer resquícios de flexibilidade, tornando-se "rígidas" - ou seja, escritas e não passíveis de modificação pela autoridade legislativa ordinária - e dotadas de plena eficácia normativa ${ }^{93}$ - ou seja, aptas a tutelar direta e imediatamente todas as situações que contemplam ${ }^{94}$. A lei, portanto, deixou de ter sua validade exclusivamente condicionada ao procedimento seguido para sua criação (validade formal) e passou a ser

\footnotetext{
${ }^{90}$ BARROSO, Luis Roberto. Fundamentos teóricos e filosóficos do Direito Constitucional brasileiro. Disponível em: <http://jus2.uol.com.br/doutrina/texto.asp?id=3208>. Acesso em: 16 mai. 2009.

${ }^{91}$ CAMBI, Eduardo. Neoconstitucionalismo e neoprocessualismo. In: FUX, Luiz; NERY JR., Nelson; WAMBIER, Teresa Arruda Alvim. Processo e Constituição: estudos em homenagem ao Professor José Carlos Barbosa Moreira. São Paulo: Revista dos Tribunais, 2006. Cap. 56, p. 662-683.

92 CAPPELLETTI, Mauro. O controle judicial de constitucionalidade das leis no direito comparado. Trad. Aroldo Plínio Gonçalves. $2^{a}$ ed. Porto Alegre: Sergio Antonio Fabris Editor, 1999. p. 12.

${ }^{93}$ MARINONI, Luiz Guilherme. Teoria geral do processo. p. 46.

${ }^{94}$ BARROSO, Luis Roberto; BARCELOS, Ana Paula de. O começo da história. A nova interpretação constitucional e o papel dos princípios no direito brasileiro. Disponível em: <http://www.camara.rj.gov.br/setores/proc/revistaproc/revproc2003/arti_histdirbras.pdf>. Acesso em: 18 mai. 2009.
} 
controlada, aplicada e interpretada a partir da Constituição (validade substancial).

Essa mudança paradigmática, evidentemente, influenciou no papel desempenhado por juízes, advogados, professores e juristas de uma forma geral. Se outrora bastava a simples aplicação mecânica de normas formalmente válidas, agora o intérprete deve ter, nas palavras de Luiz Guilherme Marinoni, "uma compreensão crítica da lei em face da Constituição, para ao final fazer surgir uma projeção ou cristalização da norma adequada, que também pode ser entendida como 'conformação da lei'". Com isso, o intérprete, e principalmente o juiz, passa a exercer sua função com maior liberdade interpretativa e criativa ${ }^{95}$, na medida em que não está mais adstrito à simples revelação da palavra da lei, mas sim na sua conformação aos princípios de justiça e aos direitos fundamentais ${ }^{96}$.

Isso não significa dizer, obviamente, que basta afirmar que determinada norma, quando aplicada ao caso concreto, não se coaduna aos princípios de justiça e aos direitos fundamentais, para que sua aplicabilidade seja de pronto afastada. Até porque, em função de seu conteúdo aberto, principiológico e extremamente dependente da realidade subjacente, esses princípios nem

\footnotetext{
${ }^{95}$ Sobre a importância do intérprete na nova dogmática constitucional, vale destacar, pela beleza, as palavras de Mauro Cappelletti: "Mas a verdadeira, a grande novidade está (...) na tentativa de transformar a imprecisão e a imóvel estaticidade daquelas fórmulas e a inefetividade daquela prevalência em uma efetiva e dinâmica e permanente 'concretização', através da obra de um intérprete qualificado - o juiz, ou, nos sistemas mais recentes, o especial juiz constitucional. Aqui, verdadeiramente, o gênio dos homens atingiu o seu vértice; a aspiração ao eterno, uma aspiração que renasce perenemente de suas próprias cinzas, encontra aqui a sua concreta conciliação com a realidade; a eternidade dos valores, aquela eternidade que a história mostrou ser impossível e também sempre suprema utopia da humanidade, concretiza-se através do trabalho atuante do juiz. E também a mil vezes derrotada aspiração jusnaturalista encontra, assim, a sua própria dimensão real, o seu rosto humano; jusnaturalismo e positivismo reconciliam-se, fundem-se nesta certamente imperfeita, mas, genial, invenção do homem e do Direito." (CAPPELLETTI, Mauro. O controle judicial de constitucionalidade das leis no direito comparado. p. 12).

${ }^{96}$ MARINONI, Luiz Guilherme. Teoria geral do processo. p. 46-47.
} 
sempre apresentam uma solução unívoca, um único caminho a ser trilhado ${ }^{97}$. Pelo contrário, na maioria das vezes, apontam caminhos conflitantes e sua aplicação depende diretamente das escolhas realizadas pelo intérprete. E, quando se fala em escolhas, abre-se espaço para dois perigosos elementos da arbitrariedade: a subjetividade e a discricionariedade.

Por essa razão que, ultrapassado um primeiro momento de franca euforia com a redescoberta do valor dos princípios, a doutrina moderna logo passou a dedicar sua atenção à contenção da discricionariedade do intérprete (principalmente do juiz), em especial com a demarcação de parâmetros para a ponderação de valores e interesses no caso concreto, e com a exigência de demonstração fundamentada da racionalidade e do acerto de suas opções ${ }^{98}$. A atuação do intérprete, portanto, agora necessariamente mais criativa e livre (ou menos presa), passa a ter sua legitimidade vinculada à precisa justificação racional de suas escolhas. Ou seja, à medida que se amplia a liberdade, exigese uma tarefa mais responsável e trabalhosa por parte do intérprete, condizente com a grandiosidade de sua nova função constitucional.

Diante de tudo o que foi falado até aqui, pode-se chegar às seguintes conclusões: (i) a norma não desfruta mais da onipotência dos tempos do positivismo e passa a ser controlada, aplicada e interpretada a partir da Constituição $^{99}$; (ii) a função do intérprete não está mais adstrita à simples

\footnotetext{
${ }^{97}$ BARROSO, Luis Roberto; BARCELOS, Ana Paula de. O começo da história. A nova interpretação constitucional e o papel dos princípios no direito brasileiro. Disponível em: $<$ http://www.camara.rj.gov.br/setores/proc/revistaproc/revproc2003/arti_histdirbras.pdf>. Acesso em: 18 mai. 2009.

${ }^{98}$ Nesse sentido, destaca-se a importância das obras de Robert Alexy (Teoria da argumentação jurídica) e Ronald Dowrkin (Uma questão de princípio). No Brasil, destaca-se a obra de Humberto Ávila (Teoria dos princípios) que, rompendo com alguns conceitos de Alexy e Dowrkin, apresenta uma proposta autêntica para aplicação e interpretação das normas jurídicas.

${ }^{99}$ BARROSO, Luis Roberto; BARCELOS, Ana Paula de. O começo da história. A nova interpretação constitucional e o papel dos princípios no direito brasileiro. Disponível em: $<$ http://www.camara.rj.gov.br/setores/proc/revistaproc/revproc2003/arti_histdirbras.pdf>. Acesso em: 18 mai. 2009. Nas palavras dos autores: “(...) a Constituição passa a ser a lente através da qual se lêem e se interpretam todas as normas infraconstitucionais."
} 
revelação da palavra da lei, mas sim na sua conformação aos princípios de justiça e aos direitos fundamentais assegurados na Constituição; (iii) a superabilidade de uma norma, conquanto possível, depende da demonstração fundamentada de sua racionalidade, de forma que a discricionariedade do intérprete possa ser controlada e não revele apenas uma renovada face da arbitrariedade.

Pois bem. Uma vez que a aplicação da teoria das cargas probatórias dinâmicas no processo civil brasileiro depende da superação da norma do art. 333 do CPC, buscar-se-á, sem a pretensão, obviamente, de esgotar todos os argumentos sobre a matéria, uma justificativa racional que legitime esta superação.

Em primeiro lugar, deve-se lembrar que a regra de repartição do encargo probatório, assim como qualquer outra regra disposta no ordenamento jurídico brasileiro, tem uma finalidade subjacente. E, nesse caso, não apenas uma.

Como visto no primeiro capítulo deste estudo, o ônus da prova pode ser compreendido sob uma dupla perspectiva. Subjetivamente, atua de forma decisiva na atividade probatória das partes, delineando suas expectativas e orientando suas atuações. Objetivamente, permeia a condução do processo pelo juiz e, caso não sejam suficientemente esclarecidos os fatos controvertidos, permite o julgamento da causa.

Assim, repartir o ônus da prova é importante para (i) dar ciência às partes acerca dos fatos que incumbem a cada uma demonstrar no processo, de forma que possam avaliar e organizar suas respectivas atividades probatórias; (ii) auxiliar o juiz na condução do processo, de forma que o possibilite a 
esclarecer as partes sobre os rumos da instrução ${ }^{100}$; e (iii) apontar qual dos litigantes deve suportar a inexistência/insuficiência da instrução probatória, de forma que o juiz possa decidir o litígio, já que o CPC veda o non liquet.

É justamente para atender estas finalidades que o CPC determina, expressamente, que a prova dos fatos constitutivos incumbe ao autor, e a prova dos fatos impeditivos, extintivos ou modificativos incumbe ao réu. Mas - como qualquer avanço começa a partir de questionamentos - por que distribuir o ônus da prova dessa maneira? Por que não manter a regra herdada do direito romano e determinar que o ônus da prova deva recair inteiramente sobre a cabeça do autor ${ }^{101}$ ?

A resposta é simples. Há um fundamento por detrás desta distribuição:

O fundamento da repartição do ônus da prova entre as partes é, além de uma razão de oportunidade e de experiência, a idéia de eqüidade resultante da consideração de que, litigando as partes e devendo conceder-se-lhes a palavra igualmente para o ataque e a defesa, é justo não impor só a uma o ônus da prova (do autor não se pode exigir senão a prova dos fatos que criam especificamente o direito por ele invocado; do réu, as provas dos pressupostos da exceção) ${ }^{102}$.

Percebe-se que a própria regra de repartição do ônus da prova está fundada na idéia de equiidade e na necessidade de se conceder um tratamento igualitário e justo a ambos os litigantes. É evidente; se as partes litigam em pé de igualdade e, assim sendo, não há razões para preferir-se a mera alegação de um à simples alegação do outro, nada mais justo do que exigir de ambos a prova de suas respectivas alegações.

\footnotetext{
${ }^{100}$ DINAMARCO, Cândido Rangel. A instrumentalidade do processo. p. 249.

${ }^{101}$ A regra, em questão, é evidenciada nos seguintes brocardos latinos: onus probandi incumbit actori (ônus da prova incumbe ao autor), necessitas probandi incumbit ei qui agit (ônus da prova incumbe a quem aciona) e actori non probante, reus est absolvendus (não havendo provado o autor, o réu deve ser absolvido). No próprio direito romano, esta regra foi superada e o ônus da prova passou a ser atribuído a quem afirma o fato: ei incumbit probatio qui dicit, non qui negat (ônus da prova incumbe a quem afirma, não a quem nega). Percebe-se que a regra desenvolvida por Giuseppe Chiovenda, e recepcionada no processo civil brasileiro, nada mais é do que uma evolução desta última regra romana. 102 CINTRA, Antonio Carlos de Araújo; GRINOVER, Ada Pellegrini; DINAMARCO, Cândido Rangel. Teoria Geral do Processo. 23 ${ }^{\mathrm{a}}$ ed. São Paulo: Malheiros Editores, 2007. p. 373.
} 
Portanto, muito além de simplesmente repartir o ônus da prova, indicando às partes quais fatos a cada uma incumbe provar e ao juiz quem deve suportar o peso de sua dúvida, a regra do art. 333 do CPC tem como finalidade assegurar uma distribuição equânime do onus probandi, garantindo a igualdade e a justiça entre os litigantes. E, embora abstratamente pareça atingir seu escopo com virtuosa racionalidade, a prática tem demonstrado que, diante de determinadas e excepcionais situações de direito material, sua aplicação tem servido apenas como celebração da desigualdade das partes e instrumento de inúmeras injustiças ${ }^{103}$.

É o que ocorre, por exemplo, nos casos em que se defende a aplicabilidade da teoria das cargas probatórias dinâmicas. Quando, seja pela própria natureza do direito material discutido, seja pela real proximidade das partes em relação aos meios de prova, há evidente desequilíbrio entre a possibilidade probatória das partes, a aplicação da regra do art. 333 pode representar, a partir da manutenção de uma desigualdade de fato, a impossibilidade de se garantir a tutela de um direito assegurado pelo ordenamento jurídico, uma vez que o cumprimento do encargo probatório, na

\footnotetext{
103 É importante lembrar que estas situações não se resumem aos casos em que há evidente desequilíbrio entre a possibilidade probatória das partes, quando, então, a teoria das cargas probatórias dinâmicas representaria a melhor saída para o problema. Existem outras situações que, apesar de extrapolarem a proposta deste estudo, também exigem um tratamento diferenciado diante da tradicional regra de repartição do encargo probatório. Nesse sentido, discorrem Luiz Guilherme Marinoni e Sérgio Cruz Arenhart: "Como o juiz deve se convencer de algo que está no plano de direito material, não há como exigir uma convicção uniforme para todas as situações de direito substancial. Em alguns casos, como os de lesões pré-natais, de seguro e relativos a atividades perigosas, a redução das exigências de prova ou de convicção de certeza é justificada pela própria estrutura e natureza dessas situações. Por isso, diante delas é admitida a convicção de verossimilhança. Tais situações têm particularidades próprias, suficientes para demonstrar que a exigência de prova plena seria contrária ao próprio desejo do direito material. Nelas, o próprio direito material não se concilia com a aplicação da regra do ônus da prova." (MARINONI, Luiz Guilherme; ARENHART, Sérgio Cruz. Curso de Processo Civil v. 2: Processo de Conhecimento. p. 273-274).
} 
maioria das vezes, corresponde à própria obtenção da tutela do direito reclamado $^{104}$.

Nessas situações, fica evidente a incompatibilidade entre a finalidade da regra (assegurar uma distribuição justa e igualitária) e aquilo que sua hipótese abstrata estabelece. Essa incompatibilidade, por si só, além de demonstrar a fragilidade da regra, fornece argumentos suficientes para que se determine sua superabilidade, sobretudo por revelar verdadeiro atentado ao direito fundamental à ordem jurídica justa e efetiva (art. $5^{\circ}$, inciso $\mathrm{XXXV}$, da $\mathrm{CF}$ ). Dessa forma, a superação da regra do art. 333, desde que observadas as particularidades do caso concreto, não é só racionalmente possível, mas constitucionalmente necessária.

Por outro lado, não se pode esquecer que a teoria das cargas probatórias dinâmicas, exceção ora analisada à regra do art. $333^{105}$, apesar de não estar expressamente prevista, encontra respaldo no próprio ordenamento jurídico brasileiro. Sua aplicabilidade pode ser justificada a partir da compreensão dos seguintes fundamentos:

\subsubsection{Acesso à justiça}

\footnotetext{
${ }^{104} \mathrm{O}$ constitucionalista português José Joaquim Gomes Canotilho, ao analisar a relação de dependência entre as regras de distribuição do ônus da prova e a tutela efetiva dos direitos fundamentais, segue a mesma linha de raciocínio seguida neste estudo, embora não apresente qualquer solução concreta: "Compreende-se que, quando a medida justa da distribuição do ónus da prova é fundamental para a garantia de um direito, se devam evitar teorias abastractas e apriorísticas (...) e se imponham soluções probatórias não aniquiladoras da própria concretização de direitos, liberdades e garantias." (CANOTILHO, José Joaquim Gomes. O ónus da prova na jurisdição das liberdades. In: CANOTILHO, José Joaquim Gomes. Estudos sobre Direitos Fundamentais. $1^{\text {a }}$ ed. São Paulo: Revista dos Tribunais, 2008. Cap. 9, p. 169-175).

${ }^{105}$ Mas, evidentemente, não a única possível, uma vez que só tem aplicabilidade em uma das diversas situações em que a regra do art. 333 não é a solução mais adequada (vide nota de rodapé $\mathrm{n}^{\circ} 104$, por exemplo).
} 
$\mathrm{O}$ direito fundamental de acesso à justiça, previsto no art. $5^{\circ}$, inciso XXXV, da CF, na sua atual compreensão, não se limita à mera garantia do direito formal do indivíduo de propor ou contestar uma ação, mas compreende a garantia de acesso à ordem jurídica justa e efetiva.

Conforme demonstrado anteriormente, a aplicação irrestrita da regra do art. 333 do CPC pode representar, em última análise, a própria impossibilidade de se obter a tutela efetiva do direito reclamado, uma vez que, ao onerar a parte com encargo probatório impossível de ser cumprido, determina de antemão sua sorte no processo. Com isso, irrelevante garantir o acesso da parte hipossuficiente ao judiciário se, em função da manutenção de um obstáculo intransponível e desarrazoado, a legislação processual beneficia a parte que, muito embora se encontre em posição mais favorável para produzir a prova, frustra o esclarecimento dos fatos controvertidos através de sua inércia.

Dessa forma, a teoria das cargas probatórias dinâmicas age de forma a restabelecer a própria efetividade e justiça da jurisdição, tendo em vista que distribui o encargo de acordo com a possibilidade probatória de cada um. Assim, a necessidade de se produzir provas volta a ser um ônus, no sentido de depender apenas do interesse da parte onerada para que seja cumprido, e deixa de representar uma perda preestabelecida.

\subsubsection{Princípio da igualdade}

A teoria das cargas probatórias dinâmicas nada mais é do que a aplicação do princípio da igualdade, previsto no art. $5^{\circ}$, caput, da $\mathrm{CF}$, na sua feição mais moderna. Isso porque trata desigualmente partes desiguais, na exata medida das desigualdades do caso concreto. 
A partir do desequilíbrio entre a possibilidade probatória das partes, a teoria fornece uma proposta de distribuição racional do ônus da prova que, na maioria das vezes, acentua o encargo probatório de uma e atenua o da outra. Este tratamento, apesar de revelar aparente desrespeito ao princípio da igualdade, é justificado na necessidade de se garantir a efetiva paridade de armas entre as partes, de forma que ambas "desfrutem concretamente das mesmas oportunidades de sucesso final" ${ }^{106}$ no processo ${ }^{107}$.

Além da garantia constitucional, o CPC, ao dispor sobre os deveres do juiz durante a condução do processo, determina que lhe compete assegurar às partes igualdade de tratamento (art. 125). Com isso, fica claro que a distribuição dinâmica do ônus da prova, longe de representar apenas uma possibilidade, é, ela própria, um dever do juiz.

\subsubsection{Princípio da solidariedade e o dever de colaboração}

O princípio da solidariedade e o dever de colaboração, fundamentos determinantes para a formulação da teoria na Argentina, estão indiscutivelmente consagrados no ordenamento jurídico brasileiro, conforme se extrai, por exemplo, do art. $3^{\circ}$ da CF que, ao enumerar os objetivos da República Federativa do Brasil, estipula, dentre eles, o de construir uma sociedade livre, justa e solidária (inc. I).

No Código de Processo Civil, estão presentes (i) no dever dos litigantes de contribuírem com a descoberta da verdade (arts. 14, I, e 339 do CPC), (ii)

\footnotetext{
106 GRECO, Leonardo. As garantias fundamentais do processo: o processo justo. Disponível em: $<$ http://www.mundojuridico.adv.br/sis_artigos/artigos.asp?codigo=429>. Acesso em: 23 mai. 2009.

107 Conforme observa Antonio Janyr Dall'agnol Júnior, "só é possível igualdade, em tema de prova, quando se viabiliza a sua realização, independentemente de quem a produza." (DALL'AGNOL JR., Antonio Janyr. Distribuição Dinâmica dos Ônus Probatórios. p. 99.)
} 
na exigência de litigância de boa-fé (arts. 14, II, e 17 do CPC), e (iii) no dever do juiz de reprimir e prevenir atos contrários à dignidade da Justiça (arts. 125, III, e 600 do CPC).

Percebe-se, com isso, que a própria legislação brasileira fornece os argumentos necessários para aplicabilidade da teoria.

\subsubsection{Princípio da adaptabilidade do procedimento}

Ultrapassado o mito do procedimento único ${ }^{108}$ e vencida a utopia da criação de procedimentos diferenciados ${ }^{109}$, a doutrina processual logo percebeu que, para garantir uma adequada e efetiva tutela do direito material, o procedimento precisaria ganhar flexibilidade, de forma a se adaptar às particularidades da própria relação substancial. Nesse sentido, dispõe José Roberto Santos Bedaque:

Não se admite mais o procedimento único, rígido, sem possibilidade de adequação às exigências do caso concreto. Muitas vezes a maior ou menor complexidade do litígio exige sejam tomadas providências diferentes, a fim de se obter o resultado do processo $^{110}$.

A distribuição racional do ônus da prova é, portanto, fruto desta nova forma de encarar o procedimento, uma vez que, ao flexibilizar aquelas regras

\footnotetext{
${ }^{108}$ Fruto dos estudos da escola chiovendiana, estudado no primeiro capítulo deste estudo.

109 "Parece fácil concluir que é utópico admitir que o legislador pode construir tantos procedimentos quantos forem as situações de direito substancial carentes de tutela. Aliás, ainda que isso pudesse ser idealmente concebível, estaria esquecida a circunstância de que a evolução da sociedade, quando não faz surgir novas situações de direito material, constantemente impõe uma nova compreensão das situações pretéritas, o que impediria a sustentação de procedimentos diferenciados, pela simples razão de que o legislador sempre estaria atrasado em relação às necessidades de tutela do direito material." (MARINONI, Luiz Guilherme. Teoria geral do processo. p. 426.)

${ }^{110}$ BEDAQUE, José Roberto dos Santos. Direito e processo: influência do direito material sobre o processo. $5^{\mathrm{a}}$ ed. São Paulo: Malheiros Editores, 2009. p. 69.
} 
ordinárias, pensadas para casos simples e correntes, garante uma tutela mais adequada a situações de maior complexidade.

\subsection{5 Ônus da prova no Código de Defesa do Consumidor}

De acordo com a regra do art. $6^{\circ}$, VIII, do CDC, é direito básico do consumidor "a facilitação da defesa de seus direitos, inclusive com a inversão do ônus da prova, a seu favor, no processo civil, quando, a critério do juiz, for verossímil a alegação ou quando for ele hipossuficiente, segundo as regras ordinárias de experiências".

O intuito desta regra é tutelar adequadamente os direitos do consumidor, partindo do pressuposto que, por ser ele a parte mais fraca na relação de consumo, exigir-lhe a prova dos fatos constitutivos de seu direito pode configurar um ônus excessivo. Isso se explica pelo fato de que, geralmente, o consumidor não dispõe do acesso às informações e aos elementos técnicos do produto ou do serviço, os quais, por outro lado, estão à disposição do fornecedor, que se encontra em posição mais favorável para fornecê-los ao juiz.

Entretanto, apesar das aparentes semelhanças, não é correto afirmar que a regra de inversão do ônus da prova, consagrada no CDC, é um exemplo de recepção da teoria das cargas probatórias dinâmicas no ordenamento jurídico brasileiro. Isso porque, conforme observa Eduardo Cambi, o art. $6^{\circ}$, VIII, do $\mathrm{CDC}$ atribui ao consumidor uma vantagem processual, uma vez que o isenta de seu ônus da prova, que é transferido inteiramente ao fornecedor ${ }^{111}$. Como restou demonstrado anteriormente, esta isenção não ocorre quando se aplica a distribuição dinâmica do ônus da prova, tendo em vista que ambos os litigantes

\footnotetext{
${ }^{111}$ CAMBI, Eduardo. A prova civil. p. 412.
} 
permanecem com a necessidade de produzir provas, respeitadas as possibilidades de cada um.

Além disso, embora a inversão prevista no CDC não ocorra de forma automática (ope legis), dependendo de atuação judicial (ope iudicis), o juiz não dispõe de tanta liberdade para avaliar as circunstâncias do caso concreto, uma vez que, presente a verossimilhança da alegação ou a hipossuficiência do consumidor, é seu dever realizar a inversão do ônus da prova. Na distribuição dinâmica, por sua vez, o juiz não está adstrito a nenhum pressuposto contido na lei, devendo avaliar somente as particularidades do direito substancial discutido.

Contudo, não se pode desprezar a importância desta regra do Código de Defesa do Consumidor como elemento argumentativo para qualquer estudo que defenda a aplicabilidade do ônus dinâmico no processo civil brasileiro: através desta regra, o legislador reconheceu a insuficiência de sua regra estática de distribuição, sobretudo quando se está diante de relações em que não há qualquer paridade de armas entre os litigantes ${ }^{112}$.

\subsubsection{Interpretação sistemática}

Por outro lado, não se pode esquecer que a própria legislação brasileira não trata a regra do art. 333 do CPC como algo absoluto e insuperável. Muito pelo contrário, em diversas ocasiões, possibilita a inversão do ônus estático

\footnotetext{
${ }^{112}$ Além disso, inúmeros processualistas têm defendido uma interpretação extensiva da regra do CDC, de forma que possa ser aplicada a qualquer situação em que haja real desequilíbrio entre as partes, o que demonstra a preocupação da doutrina moderna com a flexibilização do art. 333 do CPC. Cfr.: MARINONI, Luiz Guilherme; ARENHART, Sérgio Cruz. Curso de Processo Civil v. 2: Processo de Conhecimento.
} 
através de uma série de presunções legais relativas, como, por exemplo, a presunção de quitação das parcelas anteriores, prevista no art. 322 do $\mathrm{CC}^{113}$.

$\mathrm{O}$ próprio art. 333 do $\mathrm{CPC}$, em seu parágrafo único, admite a possibilidade das partes convencionarem de forma diferente a distribuição do ônus da prova. Ora, se até mesmo os particulares podem dispor sobre a repartição do encargo probatório, não há razoabilidade em supor que o juiz também não possa reparti-lo de forma diferente e racional.

Aliás, o mesmo art. 333 demonstra a preocupação do legislador em se evitar a exigência de produção de provas diabólicas, ao afirmar que a convenção particular que distribuir de maneira diversa o ônus da prova será nula quando tornar excessivamente difícil a uma parte o exercício do direito (inc. II).

\subsubsection{Jurisprudência}

Por fim, mas não menos importante, é fundamental que se ressalte que a teoria das cargas probatórias dinâmicas já vem sendo amplamente aplicada pelos tribunais brasileiros. Se, em tempos de positivismo, a jurisprudência era considerada como fonte secundária de direito nos países de civil law, hoje, em função da nova dogmática constitucional, a jurisprudência vem ganhando uma importância cada vez maior, facilitada pelo avanço das tecnologias de informação, que permitem um acesso mais rápido e eficaz aos repositórios dos tribunais.

O Tribunal de Justiça do Estado do Rio Grande do Sul, reconhecido por suas soluções inovadoras e, nesse caso, privilegiado pela proximidade com a

\footnotetext{
${ }^{113}$ Art. 322. Quando o pagamento for em quotas periódicas, a quitação da última estabelece, até prova em contrário, a presunção de estarem solvidas as anteriores.
} 
Argentina, é o tribunal brasileiro onde se pode encontrar o maior número de julgados fundamentados abertamente na teoria das cargas probatórias dinâmicas. Pela clareza dos argumentos, destaca-se a seguinte ementa:

EMBARGOS INFRINGENTES. RESPONSABILIDADE CIVIL. ERRO MÉDICO. TEORIA DA CARGA PROBATÓRIA DINÂMICA. APLICABILIDADE DIANTE DO PECULIAR E ESCASSO MATERIAL PROBATÓRIO. 1. A utilização da técnica de distribuicão dinâmica da prova, que se vale de atribuir maior carga àquele litigante que reúne melhores condicões para oferecer o meio de prova ao destinatário que é o juiz, não se limita, no caso, apenas às questões documentais, como prontuários e exames, que se alega pertencem ao hospital, mas à prova do fato como um conjunto, ou seja, não se duvida que ao médico é muito mais fácil de comprovar que não agiu negligentemente ou com imperícia, porque aplicou a técnica adequada, do que ao leigo demonstrar que esta mesma técnica não foi convenientemente observada. 2. Quando a aplicação dos contornos tradicionais do ônus probatório na legislação processual civil não socorre a formação de um juízo de convencimento sobre a formação da culpa do médico, a teoria da carga dinâmica da prova, importada da Alemanha e da Argentina, prevê a possibilidade de atribuir ao médico a prova da sua não-culpa, isto é, não incumbe à vítima demonstrar a imperícia, a imprudência ou a negligência do profissional, mas a este, diante das peculiaridades casuísticas, a sua diligência profissional e o emprego da técnica aprovada pela literatura médica. Destarte, a aplicação de dita teoria não corresponde a uma inversão do ônus da prova, mas avaliacão sobre o ônus que competia a cada uma das partes. Incumbe, pois, ao médico especialista o ônus de reconstituir o procedimento adotado, para evidenciar que não deu causa ao ocorrido. 3. No caso dos autos, não se encontra justificativa razoável para uma fratura no braco culminar com a sua amputação, a não ser a culpa do médico que nada fez a respeito, a despeito dos sintomas indicativos da falta de melhora do autor ao longo da via crucis percorrida até descobrir, em Porto Alegre, que a dificuldade de circulação do sangue, devido à má colocacão do gesso, conduziria à perda do membro. $O$ resultado da omissão médica possui maior peso, constituindo-se, dentro desse quadro, em evidência suficiente para sua condenação, não se concebendo, sem explicacão plausível, que uma fratura sem gravidade venha a causar a perda de um membro. EMBARGOS INFRINGENTES DESACOLHIDOS, POR MAIORIA DE VOTOS.

(TJRS, Embargos Infringentes $\mathrm{N}^{\mathrm{o}}$ 70017662487, Rel. Desembargador Odone Sanguiné, Porto Alegre, 31 ago. 2007 - grifou-se) ${ }^{114}$

Além de ressaltar tudo o que já foi exposto até aqui (como, por exemplo, que "a aplicação da teoria não corresponde a uma inversão do ônus da prova"), a ementa deixa claro a importância das regras de experiência

114 TJRS, Embargos Infringentes $n^{\circ} 70017662487$, Rel. Desembargador Odone Sanguiné, Porto Alegre, 31 ago. 2007. 
comum, previstas no art. 335 do CPC, quando da aplicação da teoria. Ora, de acordo com o que acontece ordinariamente, uma simples fratura no braço não é causa suficiente para ensejar sua amputação. Nesse mesmo sentido, destaca-se outro julgamento do tribunal gaúcho:

RESPONSABILIDADE CIVIL DO MÉDICO. INJEÇÃO ERRONEAMENTE APLICADA. AMPUTAÇÃO DO ANTEBRAÇO. ÔNUS DA PROVA. DANOS MATERIAIS E MORAIS. QUANTUM. Há que reconhecer a responsabilidade do médico quando se pode constatar pelos elementos dos autos - com observância à teoria da carga probatória dinâmica -, que contribuiu de forma determinante para o evento que culminou com a amputacão do braco da autora, já que deixou de recomendar, de qualquer forma, que a aplicacão da injecão deveria se dar na região glútea, e não no braco. Ademais, posteriormente à aplicacão da injecão demorou a alcançar diagnóstico e providenciar tratamento adequado. Tendo em vista que a indenização a título de reparação de dano moral deve ter em conta a mitigação da ofensa, mas não representar um prêmio para o ofendido, é de ser mantida a fixação da sentença - 400 salários mínimos -, tendo em conta que a autora é pessoa pobre, conforme ela própria refere ao postular o benefício da AJG. APELAÇÃO E RECURSO ADESIVO DESPROVIDOS.

(TJRS, Apelação Cível n ${ }^{\circ}$ 70016300659, Rel. Desembargadora Marilene Bonzanini Bernardi, Porto Alegre, 28 dez. 2006 - grifou-se) ${ }^{115}$

Como no caso da fratura, não é razoável supor que a aplicação de uma injeção possa culminar na amputação do braço da autora, sem que tenha concorrido determinante erro médico para o evento. Nesses casos, impor a prova da culpa do médico ao autor, além de configurar a imposição de um ônus excessivo, desconsideraria a própria realidade e as regras de experiência comum.

O próprio Superior Tribunal de Justiça, corte máxima para exame de matéria infraconstitucional, já havia se manifestado expressamente, em 1996, sobre a possibilidade de aplicação da teoria em casos de responsabilidade civil por erro médico:

RESPONSABILIDADE CIVIL. MEDICO. CLINICA. CULPA. PROVA.

115 TJRS, Apelação Cível no 70016300659, Rel. Desembargadora Marilene Bonzanini Bernardi, Porto Alegre, 28 dez. 2006. 
1. NÃO VIOLA REGRA SOBRE A PROVA O ACORDÃO QUE, ALEM DE ACEITAR IMPLICITAMENTE O PRINCIPIO DA CARGA DINAMICA DA PROVA, EXAMINA O CONJUNTO PROBATORIO E CONCLUI PELA COMPROVAĈ̃O DA CULPA DOS REUS.

2. LEGITIMIDADE PASSIVA DA CLINICA, INICIALMENTE PROCURADA PELO PACIENTE.

3. JUNTADA DE TEXTOS CIENTIFICOS DETERMINADA DE OFICIO PELO JUIZ. REGULARIDADE.

4. RESPONSABILIZAÇÃO DA CLINICA E DO MEDICO QUE ATENDEU O PACIENTE SUBMETIDO A UMA OPERAÇÃO CIRURGICA DA QUAL RESULTOU A SECÇÃO DA MEDULA.

5. INEXISTENCIA DE OFENSA A LEI E DIVERGENCIA NÃO DEMONSTRADA. RECURSO ESPECIAL NÃO CONHECIDO.

(STJ, REsp no 69309/SC, Rel. Ministro Ruy Rosado de Aguiar, Brasília, 18 jun. 1996 - grifou-se $)^{116}$

Mas não é só no campo da responsabilidade profissional, principalmente médica, que se observa a aplicação da teoria. O Tribunal de Justiça do Estado do Rio de Janeiro, por exemplo, em ação de cobrança que objetivava a condenação da instituição financeira ao pagamento de expurgos experimentados em cadernetas de poupança em razão dos planos Bresser e Verão, concluiu que, à luz da teoria das cargas probatórias dinâmicas, caberia à instituição financeira a juntada dos extratos bancários relativos a períodos de quase 20 (vinte) anos atrás:

AÇÃO DE COBRANÇA. CADERNETA DE POUPANÇA. EXPURGOS DECORRENTES DOS PLANOS BRESSER E VERÃO. REJEIÇÃO DA PRELIMINAR DE ILEGITIMIDADE PASSIVA, FALTA DE INTERESSE DE AGIR E DE FALTA DE DOCUMENTOS INDISPENSÁVEIS À PROPOSITURA DA DEMANDA. DISTRIBUICÃO RACIONAL DO ÔNUS DA PROVA. PARTE AUTORA OUE JUNTA EXTRATOS PROVANDO A EXISTÊNCIA DE DEPÓSITOS EM CADERNETA DE POUPANCA Á ÉPOCA DOS PLANOS ECONÔMICOS. JUROS MORATÓRIOS QUE DEVEM FLUIR A PARTIR DA CITAÇÃO. CORREÇÃO MONETÁRIA DEVIDA DESDE O INADIMPLEMENTO. PROVIMENTO PARCIAL DO RECURSO.- Rejeita-se a preliminar de ilegitimidade passiva, ao argumento de haver o banco obedecido normas editadas pelo governo federal, uma vez que com aquele é que foi celebrado o contrato de depósito, assim como rejeita-se a preliminar de falta de interesse de agir e falta de documentos indispensáveis à propositura da ação, uma vez que a parte autora comprovou a existência de saldo em conta poupança de sua titularidade à época dos planos governamentais, bem como a data de aniversário dentro da primeira quinzena de cada mês.- Correta a inversão do ônus probatório, com base na doutrina das 
cargas probatórias dinâmicas. Conquanto este Magistrado comungue do entendimento no sentido da inaplicabilidade da Lei 8.078/90 aos contratos celebrados antes da sua entrada em vigor, na presente hipótese, é induvidoso que o apelante dispõe de melhores condicões do que o apelado para a apresentacão dos documentos imprescindíveis ao julgamento da pretensão autoral em razão de seu maior aparato tecnológico.- Os planos econômicos ensejaram aos agentes financeiros a aplicação, por inspiração governamental, de índices de correção monetária dos valores depositados em cadernetas de poupança inferiores àqueles que estavam previstos nos respectivos contratos. Tendo em vista que no momento em que o poupador deposita certa quantia na caderneta de poupança, essa quantia fica comprometida pelos trinta dias seguintes, não podendo dela dispor, sob pena de perder o rendimento, não se mostra razoável, nesse período, alterar o critério estabelecido quando do depósito.- Segundo jurisprudência do E.TJ/RJ, a correção monetária, bem como os juros remuneratórios, incidem desde o inadimplemento e os juros moratórios fluem desde a data da citação nas ações de cobrança de diferenças de rendimentos de poupança.- Provimento parcial do recurso, monocraticamente, para o fim de determinar como momento inicial para a incidência dos juros moratórios o da citação, ressalvada a incidência da correção monetária e dos juros remuneratórios desde o inadimplemento, mantendo, no mais a sentença hostilizada.

(TJRJ, Apelação Cível no 2009.001.09780, Rel. Desembargador Carlos Santos de Oliveira, Rio de Janeiro, 23 mar. 2009 - grifou-se) ${ }^{117}$

$\mathrm{Na}$ decisão, apesar do tribunal afirmar que houve inversão do ônus probatório, fica claro que o que ocorreu foi sua distribuição racional, dinâmica. $\mathrm{O}$ autor, conforme assevera a ementa, fez prova da existência da relação jurídica mantida com a instituição financeira por ocasião da implementação dos referidos planos, demonstrando, ao fornecer todos os elementos probatórios de que dispunha, sua intenção em cooperar na reconstrução dos fatos. Por outro lado, a instituição financeira, apesar de todo aparato tecnológico disponível, se manteve inerte em recuperar os extratos bancários indicados pelo autor, rompendo com seu dever de cooperação.

Além do tribunal carioca, outro exemplo é o da Câmara Especial de Meio-Ambiente do Estado de São Paulo, que vem aplicando a teoria reiteradamente em ações civis públicas ambientais, principalmente para 
atribuir as custas da realização da prova (como o adiantamento dos honorários periciais) à parte que se encontra em melhores condições para suportá-las:

AGRAVO DE INSTRUMENTO - Ação civil pública ambiental - Decisão que impôs à ré o adiantamento dos honorários periciais - Ônus da prova a cargo da requerida - Teoria das Cargas Processuais Dinâmicas que está lastrada na simples idéia de que se pode incumbir a carga probatória a quem, pelas circunstâncias do caso e sem interessar se é autor ou réu na ação, se encontre em melhor condicão para produzi-la - Recurso provido em parte apenas para reduzir o valor fixado.

(TJSP, Agravo de instrumento $\mathrm{n}^{\circ}$ 7786635200, Rel. Desembargador Samuel Júnior, São Paulo, 23 out. 2008 - grifou-se) $)^{118}$

Transcreve-se, ainda, inúmeras decisões de nossos tribunais que deixam claro que, a despeito de qualquer regra expressa possibilitando sua aplicação, a teoria das cargas probatórias dinâmicas já é uma realidade no Brasil:

APELAÇÃO CÍVEL. INDENIZAÇÃO POR DANO MORAL. ANÚNCIO INVERÍDICO OFENSIVO À HONRA DA AUTORA VEICULADO NO SITE \begin{tabular}{lllllll}
\hline DA & REQUERIDA. & RESPONSABILIDADE & DO & PROVEDOR & E & DO \\
\hline
\end{tabular} FORNECEDOR DE SERVICOS. APLICACÃO DA TEORIA DA CARGA DINÂMICA DO ÔNUS DA PROVA. VALOR DA INDENIZAÇÃO. ATENÇÃO AO CRITÉRIO PUNITIVO-PEDAGÓGICO AO OFENSOR E COMPENSATÓRIO À VÍTIMA. INAPLICABILIDADE AO CASO PELO JUÍZO A QUO DO INSTITUTO NORTE-AMERICANO DO PUNITIVE-DAMAGES. 1 Incontroverso o fato de que o anúncio registrado no site Almas Gêmeas, pertencente à requerida, foi efetuado por terceiro alheio ao processo. 2- Atuando a ré como provedora de acesso à Internet e não sendo possível a identificacão do real responsável pelo conteúdo ofensivo do anúncio, é seu o dever de indenizar pelos danos à personalidade da autora. Aplicacão da Teoria da Carga Dinâmica da Prova, ou seja, incumbe a quem tem mais condições a prova de fato pertinente ao caso. 3 - Não só como provedora de acesso em sentido amplo atuou a ré na relação em análise, como atuou também como prestadora de serviços, mesmo que gratuitamente. Evidencia-se a desmaterialização e despersonalização das relações havidas pelo uso da Internet, não sendo mais possível identificar o objeto e muito menos os sujeitos de tais relações. Assim, sendo a ré empresa que possui site na Internet de relacionamentos deve, a fim de evitar a incomensurável dimensão dos danos oriundos do mau uso de seus serviços, adotar medidas de segurança que diminuam tais riscos. (...)

(TJRS, Apelação Cível no 70013361043, Rel. Desembargador Artur Arnildo Ludwig, Porto Alegre, $21 \mathrm{dez} .2006$ - grifou-se) ${ }^{119}$

118 TJSP, Agravo de Instrumento nº 7786635200, Rel. Desembargador Samuel Júnior, São Paulo, 23 out. 2008. 
APELAÇÕES CÍVEIS. ACC̃̃O DE REVISÃO DE CONTRATO GARANTIDO POR ALIENACÃO FIDUCIÁRIA. AUSÊNCIA DO CONTRATO OBJETO DA PRETENDIDA REVISÃO. Caso em que o contrato objeto da pretensão revisional não veio aos autos, ônus que cabia à instituicão financeira, pela observância ao princípio da carga dinâmica da prova. Inteligência, ainda, do artigo 355 do CPC. SENTENÇA DESCONSTITUÍDA DE OFÍCIO. APELOS PREJUDICADOS.

(TJRS, Apelação Cível no 70017420225, Rel. Desembargador Isabel de Borba Lucas, Porto Alegre, 07 dez. 2006 - grifou-se) ${ }^{120}$

ASSISTÊNCIA JUDICIÁRIA GRATUITA. IMPUGNAÇÃO JULGADA PROCEDENTE. AUSÊNCIA DE PROVA DA HIPOSSUFICIÊNCIA. ALUSÃO À GARANTIA CONSTITUCIONAL. APLICACÃO DA TEORIA DA DISTRIBUIÇÃO DINÂMICA DA PROVA. Mantém-se o decreto judicial que acolhe a impugnação à gratuidade judiciária, quando o impugnado deixa de comprovar com suficiência sua impossibilidade em atender os ônus do processo e os elementos colacionados aos autos evidenciam a potencia financeira dos litigantes. $\underline{\mathbf{A}}$ garantia constitucional que assegura o benefício da assistência jurídica integral e gratuita exige, além da simples "afirmacão" da pobreza", também a "comprovacãa" da hipossuficiência de recursos (CF, art. $5^{\circ}$, LXXIV), o que enseja a discricionariedade judicial em sua avaliação. Cabe ao requerente, assim, como parte mais habilitada, cumprir a demonstração, em respeito à "teoria da distribuicão dinâmica da prova", fornecendo todos os elementos de convicção que persuadam sobre alegada hipossuficiência. APELO DESPROVIDO. (SEGREDO DE JUSTIÇA)

(TJRS, Apelação Cível no 70010284180, Rel. Desembargador José Carlos Teixeira Giorgis, Porto Alegre, 16 mar. 2005 - grifou-se) ${ }^{121}$

APELAÇÃO CÍVEL. COMERCIAL, CIVIL E PROCESSUAL CIVIL. PROTESTO INDEVIDO DE DUPLICATAS. CAUSA DEBENDI. INEXISTENCIA. ÔNUS DA PROVA. DANO MORAL IN RE IPSA. FACTORING. DIREITO DE REGRESSO. PROTESTO. DESNECESSIDADE. EXISTÊNCIA DE OUTROS PROTESTOS. SENTENÇA ULTRA PETITA. NÃOCARACTERIZAÇÃO. JUROS. TERMO INICIAL. EXTINÇÃO DA AÇÃO CAUTELAR. ANTECIPAÇÃO DE TUTELA. DESCABIMENTO. (...) A duplicata mercantil, como título causal que é, representativa de operacão comercial entre sacador e sacado, vincula-se ao negócio jurídico subjacente, podendo ser elidida a presuncão de liquidez e certeza inerente aos títulos de crédito mediante a demonstracão, por parte do sacado, de que a relação negocial, seja a prestacão de serviço, seja a entrega de mercadoria, não se efetivou. Tendo a sacada negado a existência da relação jurídica que teria dado ensejo à emissão das duplicatas protestadas, cabia à apresentante dos títulos a protesto a prova em contrário. Não se poderia exigir da sacada a prova da inexistência da relação jurídica, pois

119 TJRS, Apelação Cível no 70013361043, Rel. Desembargador Artur Arnildo Ludwig, Porto Alegre, 21 dez. 2006.

120 TJRS, Apelação Cível no 70017420225, Rel. Desembargador Isabel de Borba Lucas, Porto Alegre, 07 dez. 2006.

121 TJRS, Apelação Cível n 70010284180, Rel. Desembargador José Carlos Teixeira Giorgis, Porto Alegre, 16 mar. 2005. 
trata-se de prova negativa, conhecida também como prova impossível ou prova diabólica. Caso de aplicação do princípio da carga dinâmica da prova, o qual informa que o ônus da prova cabe à parte que melhores condições tem de produzi-la. (...)

(TJRS, Apelação Cível n ${ }^{\circ}$ 70006513477, Rel. Desembargador Adão Sérgio do Nascimento Cassiano, Porto Alegre, 15 dez. 2004 - grifou-se) ${ }^{122}$

AGRAVO DE INSTRUMENTO - Ação civil pública ambiental - Pedido de obrigação de não fazer utilizacão de fogo em cultivo da cana de acúcar e de indenização por queima realizada, com cominacões - Preliminares de falta de interesse de agir e impossibilidade jurídica do pedido afastadas - Antecipação de tutela não requerida e deferida como liminar cautelar - Descabimento - Ônus da prova a cargo da requerida - Teoria das Cargas Processuais Dinâmicas que está lastrada na simples idéia de que se pode incumbir a carga probatória a quem, pelas circunstâncias do caso e sem interessar se é autor ou réu na acão, se encontre em melhor condição para produzi-la - Recurso provido em parte apenas para afastar a antecipação da tutela.

(TJSP, Agravo de Instrumento $\mathrm{n}^{\circ}$ 7540835000, Rel. Desembargador Samuel Júnior, São Paulo, 10 jul. 2008 - grifou-se) ${ }^{123}$

\subsection{Imprevisibilidade procedimental}

Ultrapassado o primeiro óbice formulado à aplicabilidade da teoria (ausência de expressa previsão legal), resta analisar o outro argumento defendido pelos críticos: ainda que a aplicabilidade da teoria possa ser justificada a partir de uma complexa interpretação do art. 333 do CPC e de outros tantos fundamentos dispostos no ordenamento jurídico brasileiro, sua aplicação de ofício pelo juiz, no momento de sentenciar, surpreenderia as partes que estavam confiantes na incidência da regra legal, o que ofenderia as garantias constitucionais da ampla defesa e do contraditório.

A doutrina argentina, muito em parte por persistir em analisar o ônus da prova apenas como regra de julgamento, que só assumiria relevância ao juiz depois de finalizada a fase de instrução, defende que a distribuição dinâmica

122 TJRS, Apelação Cível $\mathrm{n}^{\circ}$ 70006513477, Rel. Desembargador Adão Sérgio do Nascimento Cassiano, Porto Alegre, 15 dez. 2004.

123 TJSP, Agravo de Instrumento n 7540835000 , Rel. Desembargador Samuel Júnior, São Paulo, 10 jul. 2008. 
do ônus da prova deve ser realizada por ocasião da sentença de mérito e afirma que "surpresa" não há ao litigante que, mesmo em melhores condições de produzir a prova e sabedor de seu dever de cooperar com a reconstrução dos fatos, permanece inerte no processo. Afirma que, na dinâmica processual moderna, a parte não pode alegar desconhecimento de seu dever de cooperação para se eximir de colaborar com o descobrimento da verdade ${ }^{124}$.

No entanto, muito embora se reconheça a razoabilidade do posicionamento defendido pela doutrina argentina, respaldado no próprio fundamento da teoria, acredita-se que essa linha de raciocínio não considera o dever de cooperação na sua mais moderna feição, além de não representar a melhor resposta para os críticos da teoria.

De acordo com a doutrina contemporânea, o dever de cooperação não pode ser analisado como se endereçado somente às partes. A busca da verdade real deve ser fruto da cooperação intersubjetiva de todos os sujeitos atuantes no processo. E isso, evidentemente, não exclui o juiz. Segundo a lição de Lúcio Grassi de Gouvea, o poder-dever do juiz de colaborar com as partes se desdobra em quatro deveres essenciais: (i) dever de esclarecer (o juiz não deve indeferir a petição inicial em razão da obscuridade do pedido ou da causa de pedir, sem antes pedir esclarecimento ao demandante); (ii) dever de consultar (não deve o juiz decidir questão de fato ou de direito, não discutida pelas partes, ainda que de ordem pública, antes de possibilitar o contraditório); (iii) dever de prevenir (dever de apontar as deficiências postulatórias das partes, para que possam ser supridas, antes de determinar a extinção do feito), e (iv)

\footnotetext{
${ }^{124}$ Sergio José Barberio afirma, ainda, que, da mesma forma que um advogado tem o dever de dominar as regras clássicas de distribuição do ônus da prova, tem o dever de conhecer a teoria das cargas probatórias dinâmicas, de forma a alertar o seu cliente sobre o risco de uma postura inerte no processo. Se isso é uma verdade na Argentina, onde a teoria já foi amplamente discutida e hoje é considerada como "doctrina ya recebida", o mesmo não pode ser afirmado no Brasil. Basta uma simples pesquisas entre advogados atuantes para se perceber que muitos deles desconhecem completamente a teoria e suas implicações. Cfr.: BARBERIO, Sergio José. ¿Qué debe probar el que no puede probar ?. p. 102.
} 
dever de auxiliar (dever de auxiliar as partes na remoção das dificuldades ao exercício dos seus direitos ou faculdades ou no cumprimento de ônus ou deveres processuais) ${ }^{125}$.

Portanto, levando-se em conta o alcance do instituto-princípio da cooperação intersubjetiva, corolário desta nova visão mais solidarista do processo civil, entende-se que a organização da atividade probatória (quais são os fatos controvertidos, a quem incumbe provar tais fatos e quais os meios probatórios serão empregados) deve ser realizada na audiência preliminar. Assim, o juiz, através da manutenção de um diálogo com as partes, deve adverti-las da distribuição dinâmica do ônus da prova, indicando especificamente quais fatos a cada uma incumbirá provar, de forma que haja ampla oportunidade para produção de provas.

Ainda que se esteja diante de casos em que a realização da audiência preliminar é dispensada pelo $\mathrm{CPC}^{126}$, entende-se que o mais prudente seria que o juiz, ao se deparar com a complexidade do caso, designasse a audiência, para que pudesse contar com o auxílio das partes na organização da atividade probatória. Com isso, prestigiar-se-ia a oralidade, tão esquecida, no processo civil e diminuir-se-ia a própria atividade recursal das partes, que foram anteriormente consultadas e puderam participar na fixação dos pontos controvertidos $^{127}$.

\footnotetext{
${ }^{125}$ GOUVEA, Lúcio Grassi. Cognição processual civil: atividade dialética e cooperação intersubjetiva na busca da verdade real. In: DIDIER JR., Fredie (org.). Leituras complementares de processo civil. $6^{\mathrm{a}}$ ed. Salvador: Juspodivm, 2008. Cap. 8, p. 173-187.

${ }^{126}$ Cfr.: Art. 331, § $3^{\circ}$, do CPC. Se o direito em litígio não admitir transação, ou se as circunstâncias da causa evidenciarem ser improvável sua obtenção, o juiz poderá, desde logo, sanear o processo e ordenar a produção da prova, nos termos do $\S 2^{\circ}$.

${ }^{127}$ Cfr.: WAMBIER, Luiz Rodrigues. A audiência preliminar como fator de otimização do processo. O saneamento "compartilhado" e a probabilidade de redução da atividade recursal das partes. Disponível em: <http://www.abdpc.org.br/abdpc/Artigos.asp?ordem1=artigo>. Acesso em: 25 mai. 2009.
} 
É evidente, no entanto, que não se quer aqui, depois de se defender amplamente a necessidade de flexibilização e adaptação do procedimento, a criação de uma nova regra estática. Ora, se a realização da audiência preliminar se mostrar impertinente pelas circunstâncias especiais do caso concreto, nada impede que o juiz distribua racionalmente o ônus da prova por ocasião do despacho saneador. Ainda, se o desequilíbrio probatório entre as partes só restar demonstrado depois de realizada a instrução, deve o juiz, revendo a distribuição do ônus da prova, conceder à parte prazo razoável para que produza a prova que se encontra ao seu alcance ${ }^{128}$.

O importante é que o litigante tenha plena consciência dos fatos que precisa provar, caso tenha real interesse em obter uma sentença favorável. Essa é a melhor saída, aliás, para que se harmonize a aplicação da teoria das cargas probatórias dinâmicas e o princípio da segurança jurídica, de maneira que este seja minimamente sacrificado ${ }^{129}$, e para que se evite, de uma vez por todas, objeções à teoria sob o argumento de que sua aplicação surpreenderia as partes.

A doutrina argentina, em geral, tem formulado duas críticas à repartição dinâmica do ônus da prova antes da realização da instrução: (i) a primeira, de cunho teórico, consiste em afirmar que o juiz, sob o pretexto de distribuir dinamicamente a prova, estaria prejulgando a causa em audiência; e (ii) a segunda, de cunho prático, consiste em afirmar que, em virtude do número excessivo de processos, é praticamente impossível que o juiz, por ocasião da

\footnotetext{
${ }^{128}$ Observando, obviamente, o contraditório em relação à parte contrária.

129 KNIJNIK, Danilo. As (perigosíssimas) doutrinas do "ônus dinâmico da prova" e da "situação de senso comum" como instrumentos para assegurar o acesso à justiça e superar a probatio diabolica. In: FUX, Luiz; NERY JR., Nelson; WAMBIER, Teresa Arruda Alvim. Processo e Constituição: estudos em homenagem ao Professor José Carlos Barbosa Moreira. São Paulo: Revista dos Tribunais, 2006. Cap. 77, p. 942-958. p. 944.
} 
audiência, tenha familiaridade com o litígio e suas particularidades, fato que só ocorre no momento da sentença ${ }^{130}$.

Sob o viés teórico, é importante ressaltar que a distribuição dinâmica do ônus da prova não deve jamais se dar de forma arbitrária. Não pode o juiz, em nome da aplicação da teoria, simplesmente repassar a dificuldade do demandante para o demandado, quando este também não está em condições de produzir a prova ${ }^{131}$.

A decisão que distribui o encargo, portanto, deve ser racionalmente motivada, levando em consideração os fatores (culturais, sociais e econômicos) determinantes para aplicação da teoria e a real possibilidade probatória das partes, de forma a possibilitar seu controle externo. Uma vez observada esta advertência, não há porque se falar em prejulgamento da causa, ainda mais porque o juiz - parafraseando José Carlos Barbosa Moreira - não é adivinho; não pode saber de antemão se a parte onerada produzirá ou não a prova; e, ainda que a prova seja produzida, jamais saberá a qual dos litigantes ela irá favorecer ${ }^{132}$.

\footnotetext{
${ }^{130}$ Nesse sentido, dispõe Edgar J. Baracat: "Además creo que se pone em cabeza del juez temprana e inútilmente (...) una tarea que de ordinario, por el excesivo trabajo que pesa sobre los juzgados - con una justicia de primeira instancia prácticamente colapsada por tal circunstancia -, le ha de resultar de imposible cumplimiento. En treinta y siete años en que he ejercido la profesión de abogado he sido testigo de un solo caso en que el juez que intervenía para dirimir los pleitos que se llevaban ante sus estrados sabía y conocía durante el desarrollo del litigio el tema de discusión contenido en la causa y una meridiana aproximiación de los medios probatorios ofrecidos, ya que el tiempo hábil que dispone el judicante sólo le permite atender las urgencias y los despachos del dia." (BARACAT, Edgar J. Estado actual de la teoría de la carga dinámica de la prueba con especial referencia a antecedentes jurisprudenciales y a la materia juzgada. In: PEYRANO, Jorge W. (Director); WHITE, Inés Lépori (Coordinadora). Cargas probatorias dinámicas. $1^{a}$ ed. Santa Fe: Rubinzal-Culzoni, 2008. Cap. 14, p. 267-319. p. 281.)

${ }^{131}$ CAMBI, Eduardo. A prova civil .p. 343.

${ }^{132}$ No original: "Mas, primo, o juiz não é adivinho; não pode saber de antemão a qual dos litigantes será favorável o êxito da diligência probatória." (MOREIRA, José Carlos Barbosa Moreira. O Neoprivatismo no processo civil. In: DIDIER JR., Fredie (org.). Leituras complementares de processo civil. $6^{\text {a }}$ ed. Salvador: Juspodivm, 2008. Cap. II, p. 31-53. p. 38.)
} 
Sob o viés prático, há de se reconhecer que a crítica formulada pela doutrina argentina apresenta um amargo e, infelizmente, fundado argumento. Nossos juízes, assoberbados de trabalho, muito dificilmente possuem uma intimidade maior com os litígios durante o desenrolar da fase de instrução. $\mathrm{Na}$ maioria das vezes, os processos são conduzidos "mecanicamente" até o momento da sentença, sem que o juiz possa avaliar as particularidades do caso concreto.

Entretanto, a doutrina, muito embora não possa rejeitá-la, jamais poderia se render desta maneira à prática; muito pelo contrário. O papel doutrinário é justamente apontar para um "dever-ser" ideal, onde todas as garantias e direitos seriam perfeitamente observados. Ainda que pequeno, é o primeiro passo para que mudanças efetivamente ocorram, pois, do contrário, poucas motivações existiriam para o estudo do Direito em países notoriamente corruptos como o Brasil.

De qualquer forma, como solução provisória (mas não a mais adequada, justamente por comprometer o direito fundamental à tutela jurisdicional tempestiva), poderá o juiz, ao se inteirar da complexidade da causa no momento de sentenciar, converter seu julgamento em diligência, advertindo às partes sobre a distribuição dinâmica do ônus da prova e conferindo prazo razoável para produção de provas $^{133}$.

\subsection{Anteprojeto de Código Brasileiro de Processos Coletivos}

\footnotetext{
${ }^{133}$ Cfr.: ZANFERDINI, Flávia de Almeida Montigelli; GOMES, Alexandre Gir. Cargas probatórias dinâmicas no processo civil brasileiro. Revista Dialética de Direito Processual, São Paulo, n. 69, p.1735, dez. 2008. Mensal. p. 33.
} 
Convém destacar, por fim, que a teoria das cargas probatórias dinâmicas foi acolhida, sob a influência do Código Modelo de Processos Coletivos para a Ibero-América $^{134}$, no Anteprojeto de Código Brasileiro de Processos Coletivos, elaborado pelo Instituto Brasileiro de Direito Processual:

Art. $2^{\circ}$. Princípios da tutela jurisdicional coletiva - São princípios da tutela jurisdicional coletiva:

(...)

k. dinâmica do ônus da prova

Art. 11. Provas - São admissíveis em juízo todos os meios de prova, desde que obtidos por meios lícitos, incluindo a prova estatística ou por amostragem

\$1. Sem prejuízo do disposto no artigo 333 do Código de Processo Civil, o ônus da prova incumbe à parte que detiver conhecimentos técnicos ou informações específicas sobre os fatos, ou maior facilidade em sua demonstração.

$\$ 2^{\circ}$. O ônus da prova poderá ser invertido quando, a critério do juiz, for verossímil a alegação, segundo as regras ordinárias de experiência, ou quando a parte for hipossuficiente.

$\$^{\mathbf{0}}$. Durante a fase instrutória, surgindo modificação de fato ou de direito relevante para o julgamento da causa (parágrafo único do artigo $5^{\circ}$ deste Código), o juiz poderá rever, em decisão motivada, a distribuição do ônus da prova, concedendo à parte a quem for atribuída a incumbência prazo razoável para sua produção, observado o contraditório em relação à parte contrária (artigo 25 , parágrafo $5^{\circ}$, inciso IV) ${ }^{135}$.

O Anteprojeto apresenta uma proposta de positivação da teoria bem completa, ao deixar claro que: (i) o art. 333 do CPC permanece plenamente válido como regra geral; (ii) a distribuição dinâmica do ônus probatório deve ser feita em momento anterior à fase instrutória, e (iii) a decisão que distribui o encargo probatório pode ser revista antes da sentença, desde que o juiz o faça

\footnotetext{
${ }^{134}$ O Código Modelo de Processos Coletivos para a Ibero-América, em seu art. $12, \S 1^{\circ}$, determina: O ônus da prova incumbe à parte que detiver conhecimentos técnicos ou informações específicas sobre os fatos, ou maior facilidade em sua demonstração. Não obstante, se por razões de ordem econômica ou técnica, o ônus da prova não puder ser cumprido, o juiz determinará o que for necessário para suprir a deficiência e obter elementos probatórios indispensáveis para a sentença de mérito, podendo solicitar perícias à entidade pública cujo objeto estiver ligado à matéria em debate, às custas da mesma. Se assim mesmo a prova não puder ser obtida, o juiz poderá ordenar sua realização, a cargo do Fundo de Direitos de Grupo.

${ }^{135}$ Instituto Brasileiro de Direito Processual. Anteprojeto de Código Brasileiro de Processos Coletivos. Disponível em: <http://www.direitoprocessual.org.br/dados/File/enciclopedia.doc>. Acesso em: 25 mai. 2009.
} 
motivadamente e abra prazo razoável para que a parte onerada possa produzir a prova. 


\section{CONCLUSÃO}

Atualmente, é incontestável a mudança paradigmática no estudo do processo civil. Diante da aclamada força normativa dos princípios e regras constitucionais, toda a ciência processual, outrora estruturada sob a influência dos valores liberais e do racionalismo cientificista do início do séc. XX, precisa ser repensada à luz dos objetivos e necessidades de nosso Estado Constitucional. Negar essa mudança é o mesmo que fechar os olhos para o atual estágio de desenvolvimento da sociedade, cada vez mais complexa, dinâmica e sedenta por resultados rápidos e eficazes.

A doutrina processual moderna deve, portanto, caso realmente deseje cumprir com esta grandiosa tarefa que lhe é incumbida, estar disposta a desafiar antigos "dogmas" construídos nos tempos em que o processo civil

vivia imerso em sua própria racionalidade. É preciso estar confiante para dialogar com antigos mestres, incorporando seus valiosos ensinamentos, mas sempre com a ousadia necessária para ir além de suas obras, compreendendo os anseios dos novos tempos e a necessidade natural de se manter em movimento.

É justamente essa consciência que ora permite o questionamento da, sem dúvida nenhuma brilhante, regra clássica de distribuição do ônus da prova, aperfeiçoada pelo trabalho de Giuseppe Chiovenda e consagrada no art. 333 do Código de Processo Civil brasileiro. Ora, se o processo civil consiste - em termos bem simplórios e (até mesmo) inadequados -, em uma disputa entre dois litigantes, cada qual sustentando sua versão dos fatos, sua verdade sobre os acontecimentos (não raras são as vezes em que ambos os litigantes acreditam plenamente na veracidade de suas respectivas razões, embora as duas sejam inconciliáveis), nada mais racional do que exigir que cada um produza a prova dos pressupostos fáticos da norma que lhe favorece. Ainda, se 
o autor é quem pretende a modificação do status quo ante, quem primeiro afirma, expõe sua versão, nada mais racional do que impor-lhe o ônus da dúvida, exigindo-lhe a primeira prova.

Além de possuir uma lógica inquestionável, a regra disposta no art. 333 do CPC tem, como foi visto ao longo do trabalho, a finalidade de promover uma distribuição equânime do onus probandi. Sua razão motivadora é garantir um tratamento igualitário e justo aos litigantes, partindo do pressuposto que, por litigarem as partes em igualdade de condições e devendo conceder-se-lhes a palavra igualmente para o ataque e a defesa, não é justo impor só a uma delas o ônus da prova ${ }^{136}$.

No entanto, a prática pôde demonstrar que a utilização indiscriminada da regra do art. 333 do CPC pode representar, a despeito do que sua razão motivadora propõe, a celebração da desigualdade entre as partes e um instrumento para a perpetuação de inúmeras injustiças. Isso porque, diante de determinadas situações, é materialmente impossível, ou extremamente difícil, que a parte produza a prova que lhe foi previamente incumbida, ao mesmo tempo que, à parte contrária, é plenamente possível a produção desta prova.

Diante dessas situações, como foi visto, simplesmente aplicar a regra clássica de distribuição do ônus da prova, além de representar uma afronta à própria razão motivadora da regra, constitui uma ofensa ao direito fundamental de acesso à ordem jurídica justa e efetiva (art. $5^{\circ}$, inciso $\mathrm{XXXV}$, da CF), justamente por inutilizar a demanda proposta ou a defesa manejada pela parte onerada com um encargo de impossível cumprimento (na verdade, uma perda preestabelecida, não um encargo).

\footnotetext{
136 CINTRA, Antonio Carlos de Araújo; GRINOVER, Ada Pellegrini; DINAMARCO, Cândido Rangel. Teoria Geral do Processo. p. 373.
} 
Por essa razão, numa interpretação do art. 333 do CPC de acordo com a Constituição Federal, a única conclusão razoável a que se pode chegar é que sua regra de distribuição do ônus da prova deve ser encarada apenas como uma regra geral, cuja aplicabilidade (constitucionalidade) precisará ser aferida de acordo com as particularidades do caso concreto. Quando sua aplicação for constitucionalmente indesejada, precisar-se-á, à luz das particularidades da própria relação substancial, encontrar uma solução adequada diante da Constituição Federal.

E, dentre estas soluções, está a teoria das cargas probatórias dinâmicas, cujo mandamento principal consiste em atribuir o encargo probatório à parte que se encontra em melhores condições para cumpri-lo, independentemente de sua posição no processo ou da natureza do fato probando. Apesar de inexistir regra expressa, sua aplicabilidade no processo civil brasileiro é inquestionável, exatamente por restabelecer a justiça e a efetividade da jurisdição (art. $5^{\circ}$, inciso $\mathrm{XXXV}$, da $\mathrm{CF}$ ), promover a igualdade concreta entre as partes (art. $5^{\circ}$, caput, da CF e art. 125, I, do CPC), bem como ressaltar o princípio da solidariedade e o dever de colaboração, presentes, no sistema processual brasileiro, no dever dos litigantes de contribuírem com a descoberta da verdade (arts. 14, I, e 339 do CPC), na exigência de litigância de boa-fé (arts. 14, II, e 17 do $\mathrm{CPC}$ ), e no dever do juiz de reprimir e prevenir atos contrários à dignidade da Justiça (arts. 125, III, e 600 do CPC).

Contudo, para que possa cumprir com perfeição com suas finalidades e não represente, simplesmente, a transferência abusiva da dificuldade probatória do demandante para o demandado ou vice-versa, a teoria requer a observação de duas importantes condições.

Em primeiro lugar, é preciso que a decisão que determine a distribuição dinâmica do ônus da prova seja racionalmente motivada. É necessário que o 
juiz demonstre, através de argumentos ${ }^{137}$, que a aplicação da regra do art. 333 do CPC seria inadequada ao caso concreto, por violar sua razão motivadora ${ }^{138}$ e afrontar a Constituição Federal. Além disso, deve o juiz demonstrar o efetivo desequilíbrio entre a possibilidade probatória das partes, deixando claro o motivo pelo qual a parte originariamente onerada não possui condições de cumprir com o encargo e ressaltando a posição privilegiada da outra parte, a princípio desincumbida, para cumpri-lo ${ }^{139}$. A partir da justificação racional da distribuição dinâmica, as partes poderão, através de sua atividade recursal, efetuar o controle externo desta decisão, evitando a arbitrariedade e o abuso.

Em segundo lugar, é preciso que a organização da atividade probatória (quais são os fatos controvertidos, a quem incumbe provar tais fatos e quais os meios probatórios serão empregados) ocorra em momento anterior à fase de instrução (preferencialmente na audiência preliminar, para ser fruto do diálogo entre os sujeitos atuantes no processo), de forma que as partes sejam prevenidas da aplicação da teoria e que tenham ampla oportunidade para produzir as provas que lhes foram incumbidas.

A positivação da teoria no ordenamento jurídico brasileiro seria importante para dissipar dúvidas acerca de sua aplicabilidade e para garantir o respeito a essas duas importantes condições. Entretanto, esta positivação jamais poderá ocorrer através de regras muito inflexíveis ou extremamente

\footnotetext{
137 Porque, conforme observa Robert Alexy, "argumentos são a expressão pública da reflexão." (ALEXY, Robert. Constitucionalismo Discursivo. Trad. Luís Afonso Heck. Porto Alegre: Livraria do Advogado, 2008. p. 115.)

138 Segundo a lição de Humberto Ávila, "uma regra é aplicável a um caso se, e somente se, suas condições são satisfeitas e sua aplicação não é excluída pela razão motivadora da própria regra." (ÁVILA, Humberto. Teoria dos princípios. p. 98)

${ }^{139}$ Percebe-se, aqui, um fenômeno interessante. A regra do art. 333 do CPC, apesar de não ser aplicada nesses casos excepcionais, continua a exercer um importante papel quando da aplicação da teoria das cargas probatórias dinâmicas. Isso porque o juiz só pode avaliar a possibilidade probatória das partes se tiver em mente os fatos que incumbem a cada uma provar. E, para ter essa consciência, precisa avaliar o direito material discutido à luz da regra do art. 333 do CPC e de seus encargos prévios e abstratos.
} 
casuísticas ${ }^{140}$, sob pena de dificultar e restringir a própria aplicação da teoria, que depende, fundamentalmente, da liberdade do juiz para avaliar as circunstâncias do caso concreto.

Por fim, ressalta-se que a discussão, o aperfeiçoamento e a aplicação da teoria das cargas probatórias dinâmicas representam um importante passo no aprimoramento da regra de distribuição do ônus da prova no processo civil brasileiro, mas não o único. Existem inúmeras situações que, apesar de não estarem abarcadas pela teoria, demandam por um tratamento diferenciado diante do ônus da prova, como nos casos em que nenhum dos litigantes está em condições de produzir a prova dos fatos controvertidos ou quando a própria natureza do direito material discutido não se coaduna com a exigência de prova plena...enfim, discussões que, por si sós, merecem a dedicação e a atenção de nossa doutrina.

\footnotetext{
${ }^{140}$ Como o exemplo do Anteprojeto de Código Brasileiro de Processos Coletivos que, apesar de propor uma completa proposta de positivação da teoria, acabará por atrelar sua aplicabilidade à tutela do bem jurídico coletivo.
} 


\section{BIBLIOGRAFIA}

1. ALEXY, Robert. Constitucionalismo Discursivo. Trad. Luís Afonso Heck. Porto Alegre: Livraria do Advogado, 2008. 166 p.

2. ÁVILA, Humberto. Teoria dos princípios: da definição à aplicação dos princípios jurídicos. 9ª ed. São Paulo: Malheiros Editores, 2009. $190 \mathrm{p}$.

3. BARROSO, Luis Roberto. Fundamentos teóricos e filosóficos do Direito Constitucional brasileiro. Disponível em: $<$ http://jus2.uol.com.br/doutrina/texto.asp?id=3208>. Acesso em: 16 mai. 2009.

4. ___ BARCELOS, Ana Paula de. O começo da história. A nova interpretação constitucional e o papel dos princípios no direito brasileiro. Disponível em: $<$ http://www.camara.rj.gov.br/setores/proc/revistaproc/revproc20 03/arti_histdirbras.pdf>. Acesso em: 18 mai. 2009.

5. __ Temas de direito constitucional. $2^{\mathrm{a}}$ ed. Rio de Janeiro: Renovar, 2002. $664 \mathrm{p}$.

6. BEDAQUE, José Roberto dos Santos. Direito e processo: influência do direito material sobre o processo. $5^{\text {a }}$ ed. São Paulo: Malheiros Editores, 2009. p. 69.

7. BOBBIO, Noberto. O Positivismo Jurídico: Lições de filosofia do direito. São Paulo: Ícone, 1995. 239 p.

8. CÂMARA, Alexandre Freitas. Doenças preexistentes e ônus da prova: o problema da prova diabólica e uma possível solução. Revista 
Dialética de Direito Processual, São Paulo, n. 31, p. 9-19, out. 2005. Mensal.

9. ___ Lições de Direito Processual Civil. 18 a ed. Rio de Janeiro: Lumen Juris, 2008. v. 1.528 p.

10. CAMBI, Eduardo. A prova civil: admissibilidade e relevância. São Paulo: Revista dos Tribunais, 2006. 479 p.

11. CANOTILHO, José Joaquim Gomes. Estudos sobre Direitos Fundamentais. $1^{\text {a }}$ ed. São Paulo: Revista dos Tribunais, 2008. $274 \mathrm{p}$.

12. CAPPELLETTI, Mauro. O controle judicial de constitucionalidade das leis no direito comparado. Trad. Aroldo Plínio Gonçalves. $2^{\mathrm{a}}$ ed. Porto Alegre: Sergio Antonio Fabris Editor, 1999. p. 12.

13.___. O processo civil no direito comparado. Trad. Hiltomar Martins de Oliveira. São Paulo: Líder, 2001. 115 p.

14. CARNELUTTI, Francesco. A Prova Civil. Trad. Lisa Pari Scarpa. $4^{\mathrm{a}}$ ed. Campinas: Bookseller, 2005. 324 p.

15. CHIOVENDA, Giuseppe. Instituições de Direito Processual Civil. São Paulo: Saraiva, 1969, v. 1. 352 p.

16. CINTRA, Antonio Carlos de Araújo; GRINOVER, Ada Pellegrini; DINAMARCO, Cândido Rangel. Teoria Geral do Processo. 23 ${ }^{\mathrm{a}}$ ed. São Paulo: Malheiros Editores, 2007. 383 p.

17. DALL'AGNOL JR., Antonio Janyr. Distribuição Dinâmica dos Ônus Probatórios. Revista dos Tribunais, São Paulo, v. 788, p.93-107, jun. 2001. Mensal. 
18. DIDIER JR., Fredie; BRAGA, Paula Sarno; OLIVEIRA, Rafael. Curso de Direito Processual Civil: Direito probatório, decisão judicial, cumprimento e liquidação da sentença e coisa julgada. $2^{\mathrm{a}}$ ed. Salvador: Juspodivm, 2008. 713 p.

19. - Leituras complementares de processo civil. $6^{\mathrm{a}}$ ed. Salvador: Juspodivm, 2008. $430 \mathrm{p}$.

20. DINAMARCO, Cândido Rangel. A instrumentalidade do processo. São Paulo: Malheiros Editores, 1993. 341 p.

21. ESPANHA. Ley de Enjuiciamento Civil (Ley 1/2000). $<$ http://noticias.juridicas.com/base_datos/Privado/l1-2000.html> Acesso em 02 de mai. de 2009.

22. FUX, Luiz; NERY JR., Nelson; WAMBIER, Teresa Arruda Alvim. Processo e Constituição: estudos em homenagem ao Professor José Carlos Barbosa Moreira. São Paulo: Revista dos Tribunais, 2006. $1088 \mathrm{p}$.

23. GOLDSCHMIDT, James. Teoria geral do processo. Trad. Leandro Farina. Cidade Jardim: Fórum, 2006. 170 p.

24. GRANDE, Maximiliano García. Cargas probatorias dinámicas: ni nuevas, ni argentinas, ni aplicables. Disponível em: <http://www.ederecho.org.ar/congresoprocesal/Cargas\%20Probatorias\%20Din \%E1micas\%20_Grande_pdf.> Acesso em: 02 mai. 2009.

25. GRECO, Leonardo. As garantias fundamentais do processo: o processo justo. Disponível em: $<$ http://www.mundojuridico.adv.br/sis_artigos/artigos.asp>. Acesso em: 23 mai. 2009. 
26. ___ ; NETTO, Fernando Gama de Miranda. Direito Processual e Direitos Fundamentais. Rio de Janeiro: Lumen Juris, 2005. 336 p.

27. Instituto Brasileiro de Direito Processual. Anteprojeto de Código Brasileiro de Processos Coletivos. Disponível em: $<$ http://www.direitoprocessual.org.br/dados/File/enciclopedia.do c>. Acesso em: 25 mai. 2009.

28. MARINONI, Luiz Guilherme. A questão do convencimento judicial. Disponível em: <http://www.professormarinoni.com.br>. Acesso em: 21 abr. 2009.

29. ; ARENHART, Sérgio Cruz. Curso de Processo Civil v. 2: Processo de Conhecimento. $7^{a}$ ed. São Paulo: Revista dos Tribunais, 2008. $832 \mathrm{p}$.

30. _ Técnica Processual e Tutela dos Direitos. $2^{\mathrm{a}}$ ed. São Paulo: Revista dos Tribunais, 2008. $511 \mathrm{p}$.

31.__ Teoria Geral do Processo. $3^{\mathrm{a}}$ ed. São Paulo: Revista dos Tribunais, 2008. $510 \mathrm{p}$.

32. MONTESQUIEU, Charles de. Do espírito das leis. Disponível em: <http://www.esnips.com> Acesso em: 10 mai. 2009.

33. MOREIRA, José Carlos Barbosa Moreira. Temas de direito processual: quarta série. São Paulo: Saraiva, 1989. 329 p.

34. PEYRANO, Jorge W. (Director); WHITE, Inés Lépori (Coordinadora). Cargas probatorias dinámicas. $1^{\mathrm{a}}$ ed. Santa Fe: RubinzalCulzoni, 2008. 640 p. 
35. SANTOS, Boaventura de Souza. Um discurso sobre as ciências. $5^{\text {a }}$ ed. São Paulo: Cortez, 2008. 92 p.

36. SOUZA, Wilson Alves de. Ônus da Prova: considerações sobre a doutrina das cargas probatórias dinâmicas. Revista Jurídica dos Formandos em Direito da UFBA, Salvador, v. 6, p.234-260, fev. 1999.

37. STJ, REsp nº 69309/SC, Rel. Ministro Ruy Rosado de Aguiar, Brasília, 18 jun. 1996.

38. THEODORO JR., Humberto. Curso de direito processual civil: teoria geral do direito processual civil e processo de conhecimento. $47^{\mathrm{a}}$ ed. Rio de Janeiro: Forense, 2007. 861 p.

39. TJRJ, Apelação Cível $n^{\circ}$ 2009.001.09780, Rel. Desembargador Carlos Santos de Oliveira, Rio de Janeiro, 23 mar. 2009.

40. TJRS, Apelação Cível nº 70006513477, Rel. Desembargador Adão Sérgio do Nascimento Cassiano, Porto Alegre, 15 dez. 2004.

41. TJRS, Apelação Cível nº 70010284180, Rel. Desembargador José Carlos Teixeira Giorgis, Porto Alegre, 16 mar. 2005.

42. TJRS, Apelação Cível no 70013361043, Rel. Desembargador Artur Arnildo Ludwig, Porto Alegre, 21 dez. 2006.

43. TJRS, Apelação Cível no 70016300659, Rel. Desembargadora Marilene Bonzanini Bernardi, Porto Alegre, 28 dez. 2006.

44. TJRS, Apelação Cível no 70017420225, Rel. Desembargador Isabel de Borba Lucas, Porto Alegre, 07 dez. 2006. 
45. TJRS, Embargos Infringentes $n^{\circ} 70017662487$, Rel. Desembargador Odone Sanguiné, Porto Alegre, 31 ago. 2007.

46. TJSP, Agravo de Instrumento $n^{\circ} 7540835000$, Rel. Desembargador Samuel Júnior, São Paulo, 10 jul. 2008.

47. TJSP, Agravo de Instrumento $n^{\circ} 7786635200$, Rel. Desembargador Samuel Júnior, São Paulo, 23 out. 2008.

48. WAMBIER, Luiz Rodrigues. A audiência preliminar como fator de otimização do processo. O saneamento "compartilhado" e a probabilidade de redução da atividade recursal das partes. Disponível em: $<\mathrm{http}: / / \mathrm{www}$.abdpc.org.br/abdpc/Artigos.asp?ordem1=artigo $>$. Acesso em: 25 mai. 2009.

49.ZANFERDINI, Flávia de Almeida Montigelli; GOMES, Alexandre Gir. Cargas probatórias dinâmicas no processo civil brasileiro. Revista Dialética de Direito Processual, São Paulo, n. 69, p.1735, dez. 2008. Mensal. 